محدات القيم الوجدانية فى منهاج التربية الرياضية للحلقة الثانية من

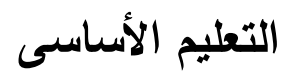

"أد/محمود عبد الحليم عبد الكريم

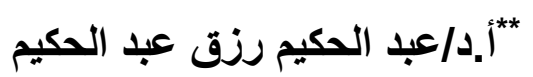

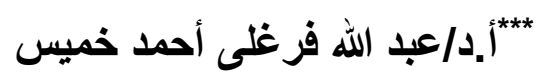

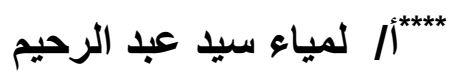

المقدمة ومشكلة البحث:

تحتل التربية الرياضية مكاناً بارزاً فى البرامج المدرسية فهي حركية فى ومى

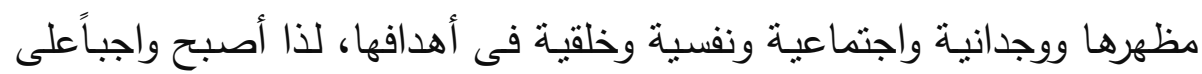

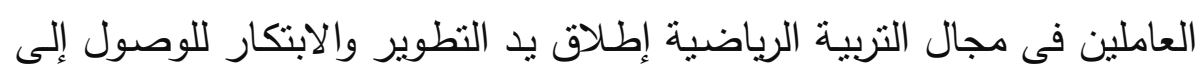

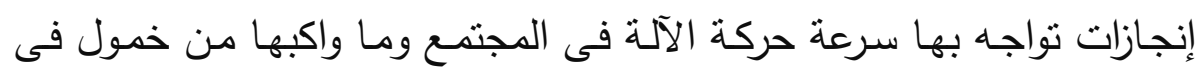
حركة التلاميذ، فالمهام لم تعد مقصورة على الدور التقليدي المعروف للجميع بل أصبح واجباً عليهم الابتكار والتجديد لترغيب الطلاب فى ممارسة النشاط لعداط الرياضي على أسس علمية تضمن لنا الاستمرارية ومواصلة التعلم والممارسـة.

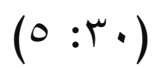

كما تسهم التربية الرياضية بدور هام فى المدرسـة الإعدادية من حيث

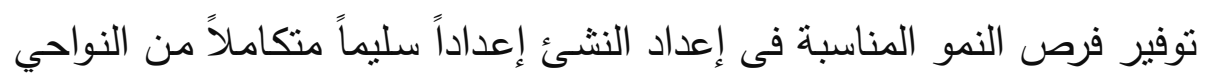
" أستاذ المناهج وطرق التدريس المتفرغ وعميد كلية التربية الرياضية (الأسبق) كلية التربية الرياضية، جامعة أسيوط. "* أستاذ علـم النفس الرياضـي ووكيـل الكليـة لشـئون التعليم والطـلاب سـابقاً، كليـة التربيـة الرياضية، جامعة أسيوط

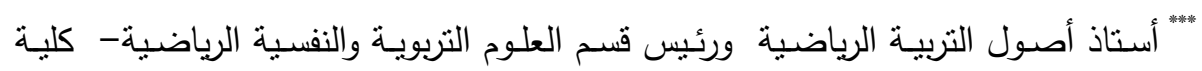
التربية الرياضية بالوادي الجديد، جامعة أسيوط التربة الرياضية باحثة من الخارج بقسم العلوم التربوية والنفسية الرياضية. مجلة أسيوط لعلوم وفنون التربية الرياضية 
البدنية والعقلية والنفسية والاجتماعية، فهي تعد عنصراً هاماً فى عمليتي النمو

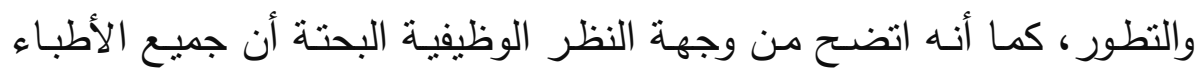
يركزوا على أهميـة النشـاط الحركي بالنسبة للأطفـال والثـباب حيـث تحتـاج أعضاء الجسم وأجهزته الحيوية إلى جزء كبير من التمرينات والأنشطة لجعلها برها قويـة ولصيانتها حتى تكون فى حالة صحية جيدة، وطالب المرحلة الإعدادية هو شاب المستقبل ورجل الدولة، ولذلك كان الإعتتاء بمناهج التربية الرياضية فـى المرحلـة الإعداديـة مسـؤية قوميـة لخلـق جيـل قـوي واع متـوازن عقليـاً

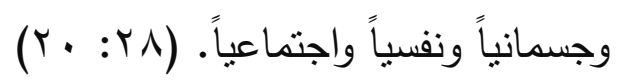

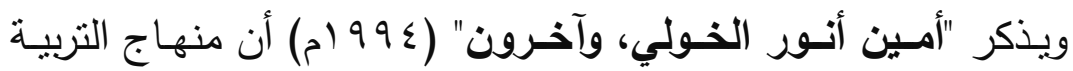

الرياضية إحدي الوسائل الرئيسية لتحقيق أهداف التربية الرياضية، وأن أهداف التربية الرياضية هي الأهداف التى تعبر عن مفاهيم وإتجاهات النظام التربوي

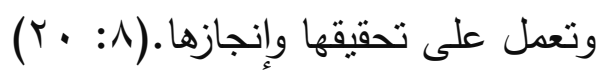

وتؤكد "ليلي عبد العزيز زهران"(r · . r م) على أنه يجب أن يتم تطوير

المنهـاج حتهى يسـاير مـا يحـدث بـالمجتمع مسن تطـوير سياسـي واجتمـاعي

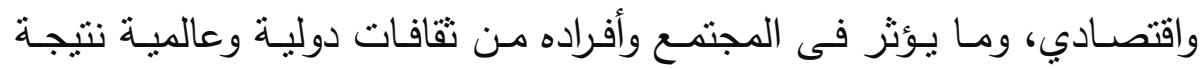

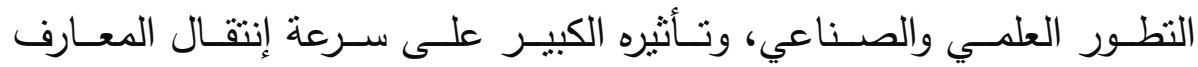
والمعلومات بين الدول المختلفة، وما يترتب على ذلك من تغيرات فى ثقافة المجتمع وحاجاته وفى ميول الأفراد واتجاهاتهم ومن ذلك يتطلب الأمر إعداد

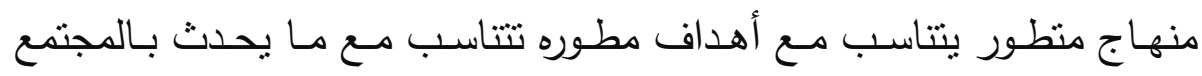
والأفراد والإمكانات من تغيرات وإضافة إلى ما سبق فإن عملية تطوير المنهاج عملية مستمرة تتطلب مراجعات دائمة للمحتوي المقرر والمواد التعليمية الأخري للتأكد من أنها تتمشي مع التغيرات التي تحدث فى المجتمع وفى مجال تدريس

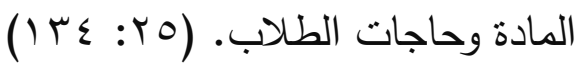


ويتفق كل من "صـلاح النمـر، مـدحت أحمد الخراشـي" (999 (م) أنه من الأمور المسلم بها أن براجع المنهاج كل خمس سنوات للتأكد من صسلاحية

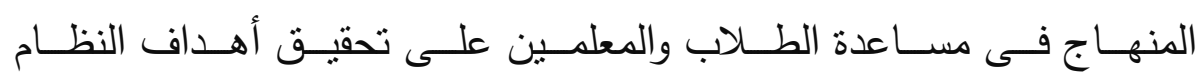

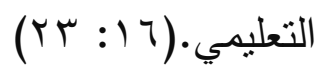

كمـا بـري كـلاً مـن "كمـال عبـــ الحمبـد، محمـــ صـبحي حســانين" (99 (م) أن درس التربيـة الرياضـية فـى المـدارس هـو البوتقـة التى يـتعلم

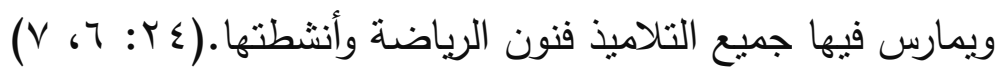

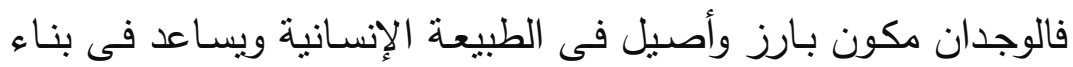
معالم نفسية إيجابية، كقوة التفكير وتوجيه السلوك، الأمر الذي يثير إلى أهمية

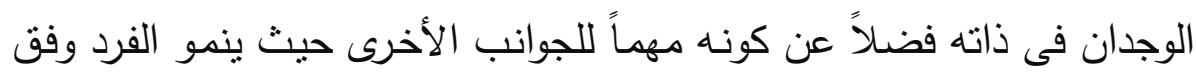

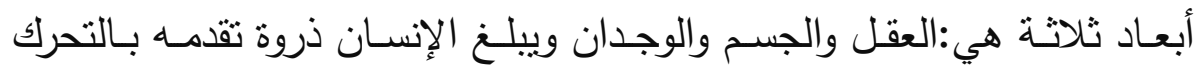
المتوازي نحو هذه الأبعاد، باسبقية محور الوجدان، وعلى ذلك فإن للتربية ثلاتثة جوانب يكمل بعضها بعضاً. - التربية العقلية والمعرفية. - التربية الوجدانية والعاطفية.

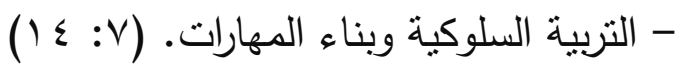
والحلقة الثانية من التعليم الاساسي هي المرحلة الإعدادية فهي تعتبر مرحلة أساسية فى بناء الفرد من حيث الشخصية المتكاملة وأعداده تعداد بمكنه مـن أداء واجباتـه نحـو مجتمـع فى شـتـي المجـالات المختلفـة وتلعـب التربيـة

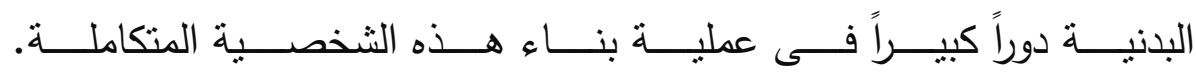
(rqr:rr)

ومن الملاحظ أن ما يتميز بـه تلميذ هذه المرحلة سرعة استجابته وتعلمهه

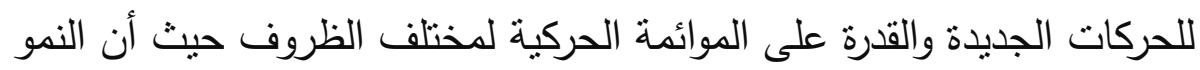


الحركي فى هذه المرحلة يصل إلى ذروته وكثيراً ما تعتبر بأنها الفترة المثلي

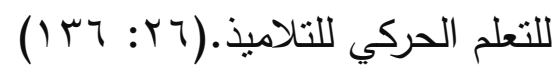

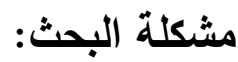

يرى الباحثون أنه يوجد في مجال التربية الرباضية من القيم مـا هو محدود وإلى جانب ذللك توجد قيم غير معلنة والتى لا تظهر إلا من الفكر الذي

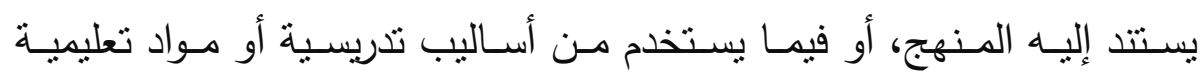
مصاحبة للمنهج من جانب المعلم. كمـا توجد مشكلة أساسـية فـى التربيـة الرياضـية وهـي قلـة المدرسـين والأدوات والأجهـزة المتاحـة بالمـدارس وقلــة اعتـراف الإدارة المدرسـية بأهميـة وضرورة حصة التربية الرياضية بالمدرسة وتأثثرها وتأثرها بالتاميذ.

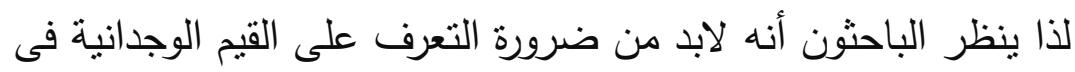
منهاج التربية الرياضية لهذه المرحلة السنية حرصاً على دفع كفاءة التلميذ خلقياً واجتماعياً وتتمية القيم الوجدانية وتتمية الشخصية لهذه المرحلة. وأن مناهج التربية الرياضية يغفل فيها الاهتمام بالقيم الوجدانية حيث

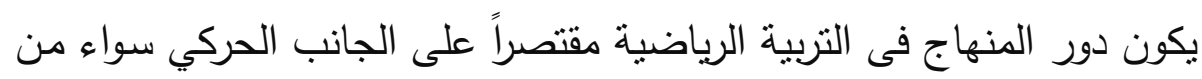

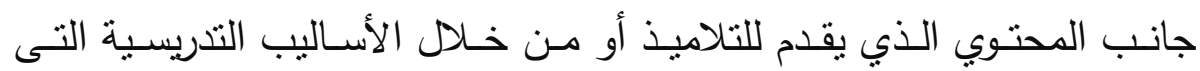
يستخدمها المعلم، وكانت مـن نتيجة ذلك ظهور اتجاهـات جديدة تدعو إلى هـ التركيز على الجانب الوجداني بكل ما يشمله من قيم وإتجاهات، حيث يكون

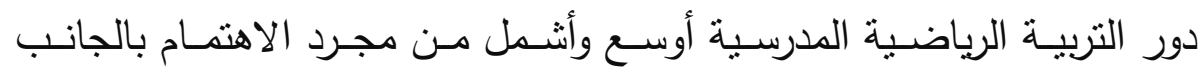
الحركي. ومن خلال إطلال الباحثّن على بعض الداراسات مثل دراسة "آمال

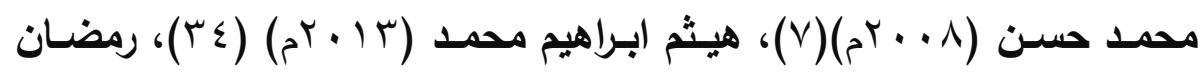

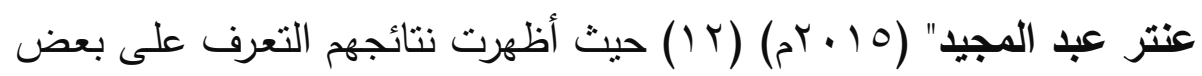

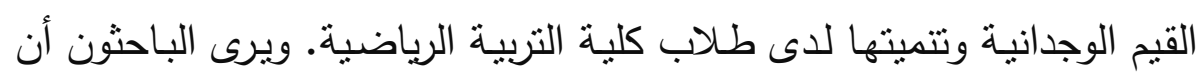
هنالك ندرة فى الدراسات التى تتطرق إلى القيم الوجدانيـة. ولذلك قام الباحثون مجلة أسيوط لعلوم وفنون التربية الرياضية 
بإجراء هذه الدراسـة بعنوان "محـددات القيم الوجدانيـة فـى منهــاج التربيـة

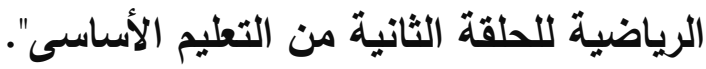

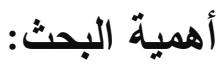

1- التعرف على القيم الوجدانيـة اللازمـة لتلاميذ الحلقـة الثانيـة مـن التعليم الأساسي بما قد يتمشي مع حاجات التناميذ فى هذه المرحلة.

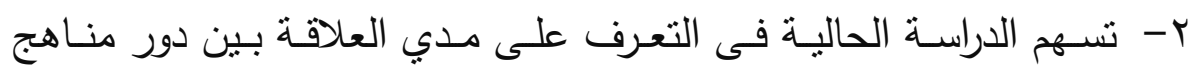

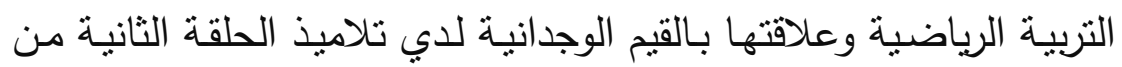
التعليم الأساسي.

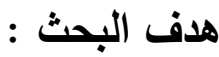
يهدف البحث الحالي إلى التعرف على محددات القيم الوجدانية فى التي منهاج التربية الرياضية للحلقة الثانية من التعليم الأساسي.

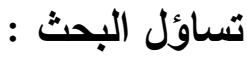
- مـا محددات القيم الوجدانيـة فى منهاج التربية الرياضية للحلقة الثنانية من

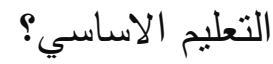

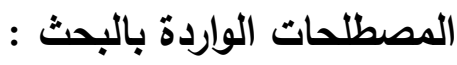

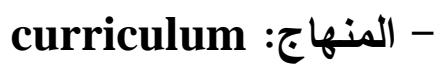
هى مجموعة الخبرات التربوية والثقافية والاجتماعية والرياضية والفنية

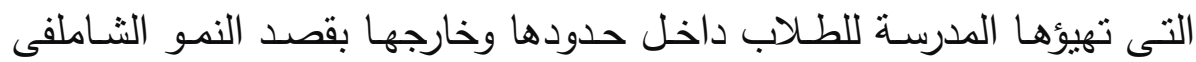

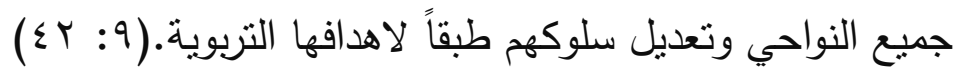
- مناهج التربية الرياضية: physical education curriculum

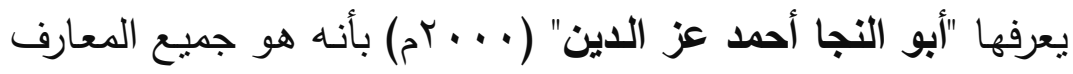

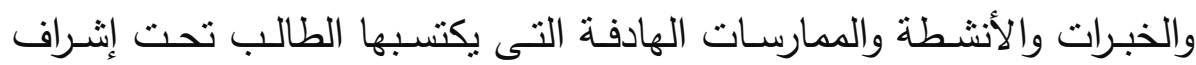
المعلم بهدف النمو الثنامل (r: (1) مجلة أسيوط لعلوم وفنون التربية الرياضية 
- القيم: Values

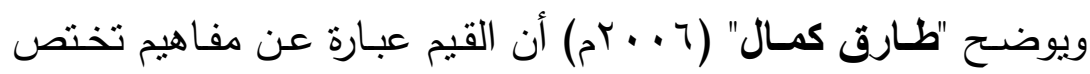

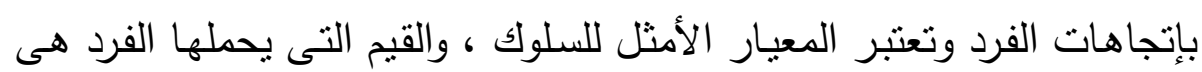

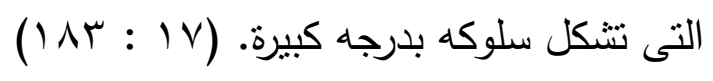

الاراسات السابقة :

الاراسات باللغة العربية.

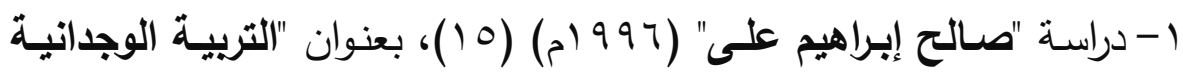

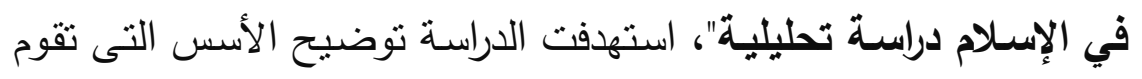

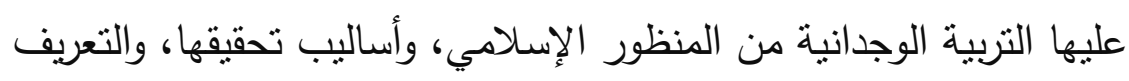

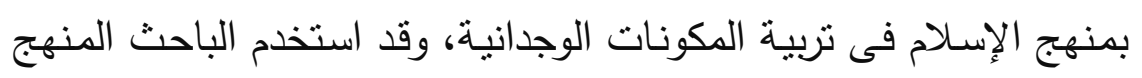

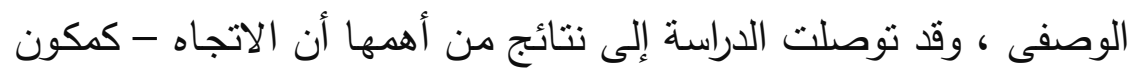

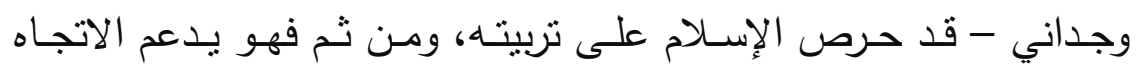

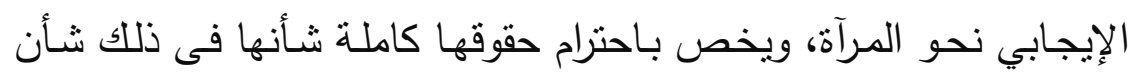

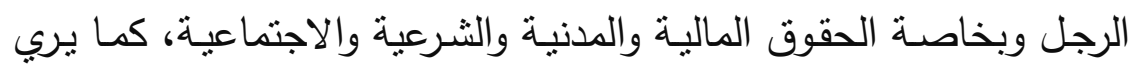

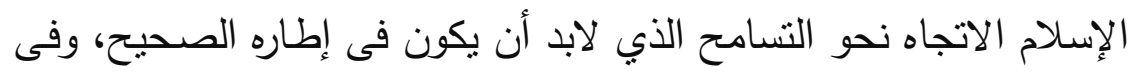

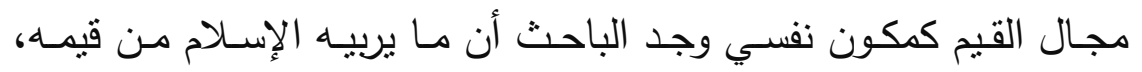

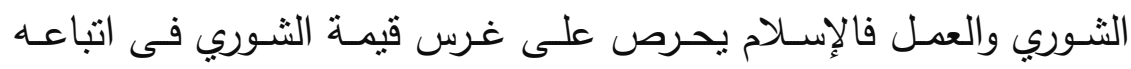
وينشئته على الاستقلال وعدم اتبعية فتكون لكل فرد من المسلمين القدرة على تكوين رأيه الخاص.

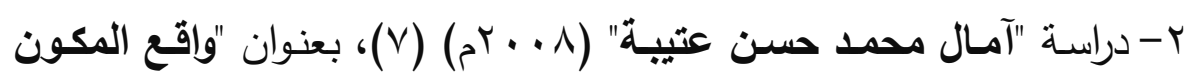

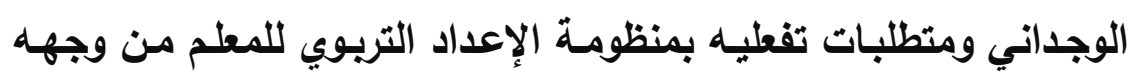

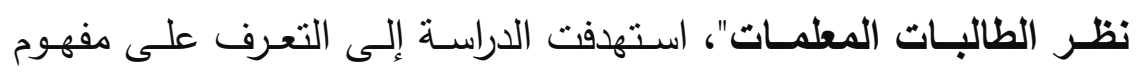

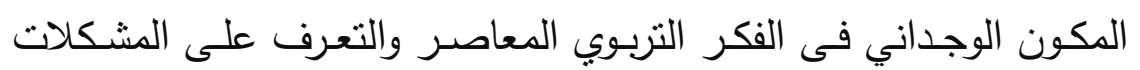

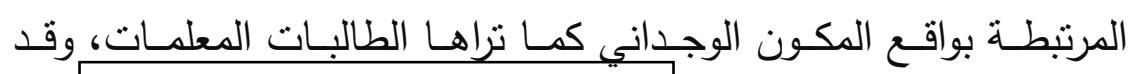
مجلة أسيوط لطلوم وفنون التربية الرياضية المبلية 
استخدمت الباحثة المنهج الوصفى ، وتوصلت الدراسة إلى نتائج من أهمها

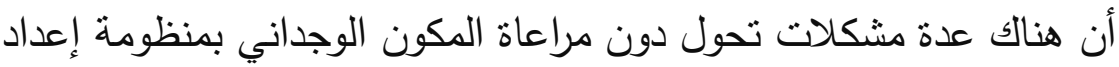

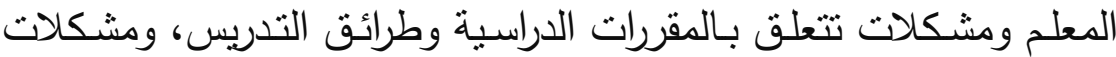
تتعلق بالأنشطة الطلابية ومشكلات تتعلق بالمستويات الإدارية.

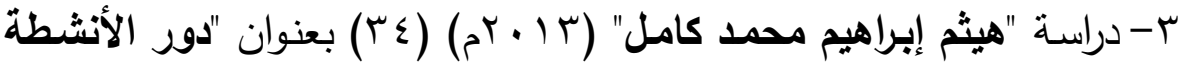
الطلابية فى تنمية المكون الوجداني لدي طلاب جامعة أسيوط (دراسـة

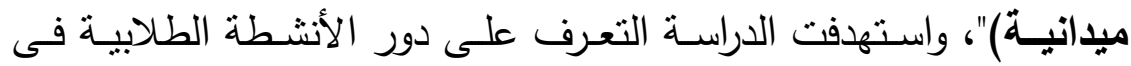

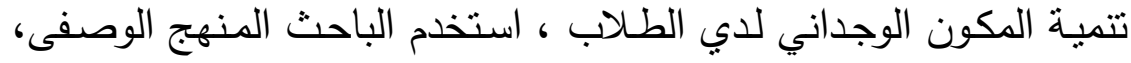

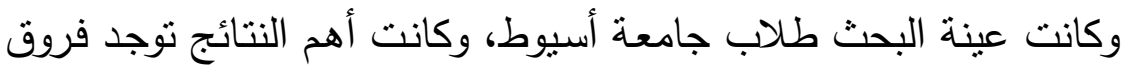

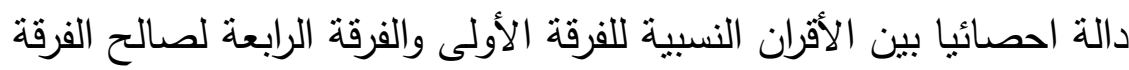
الرابعة فى 7 محاور من محاور الاستنيان وهى (التعاطف والرقابة الذاتية،

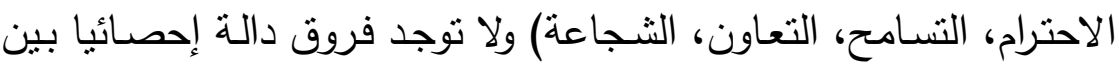

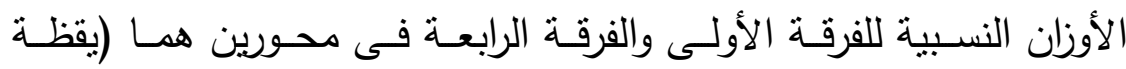

$$
\text { الضمير - العدل). }
$$

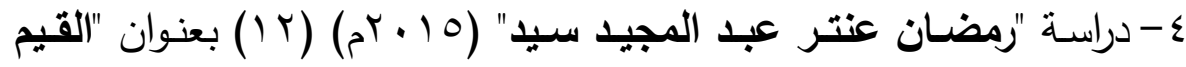

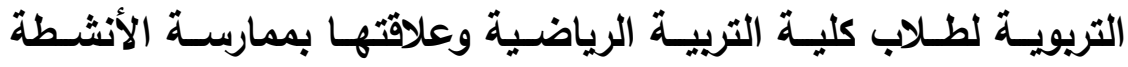

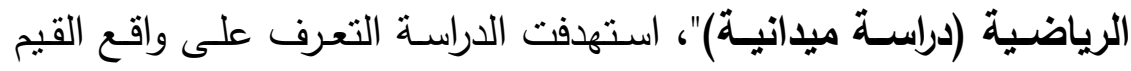

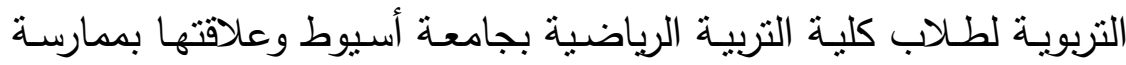

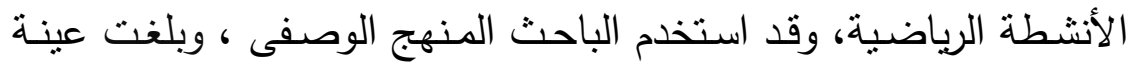

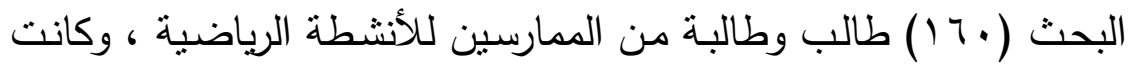

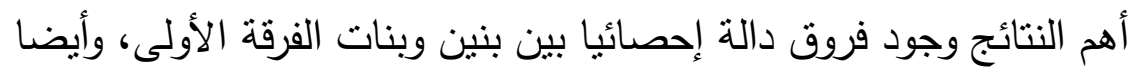

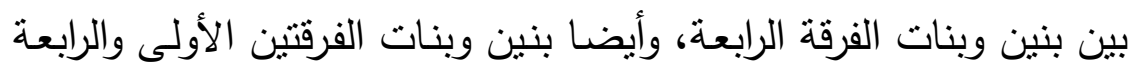

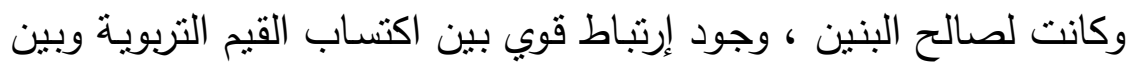
ممارسة الأنشطة الرياضية. مجلة أسيوط لعلوم وفنون التربية الرياضية

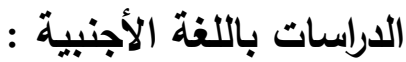


Med Calf, Richard; Marshall, Joe; rhoden, "دراسة

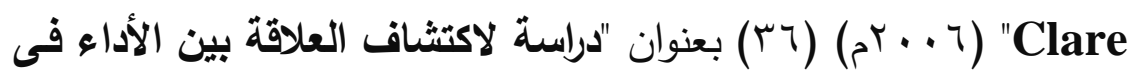

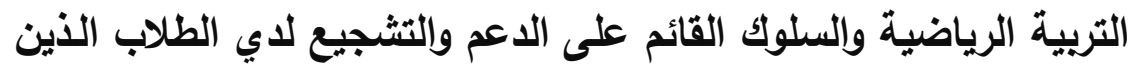

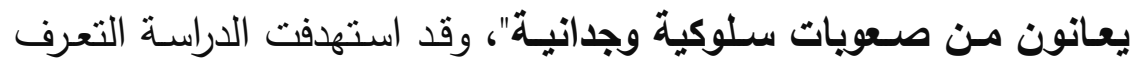

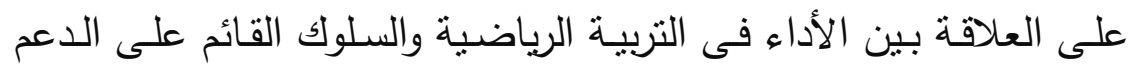

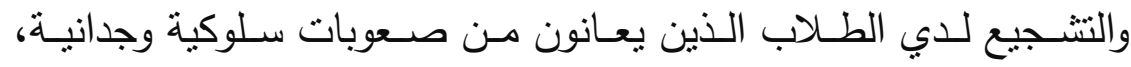

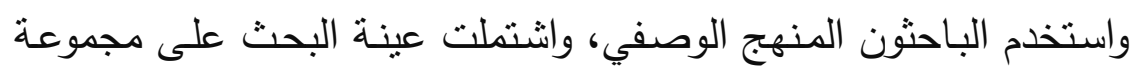

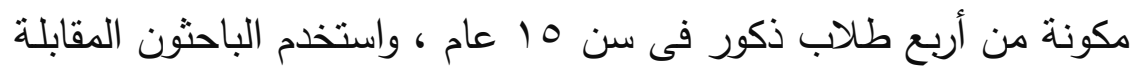

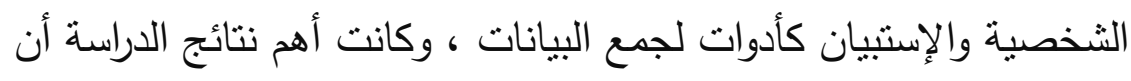

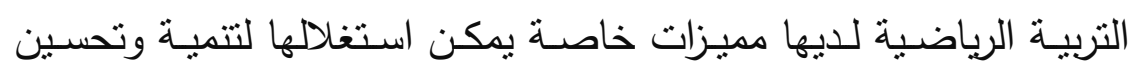

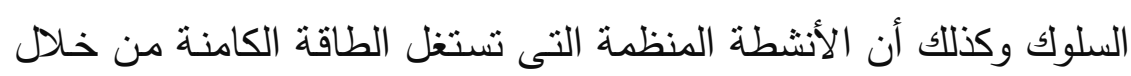

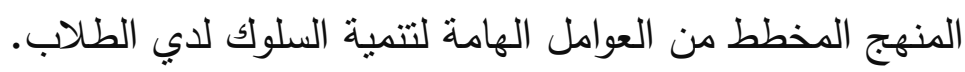
التعليق على الاراسات السابقة:

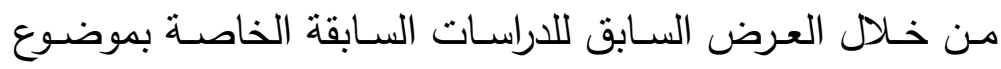

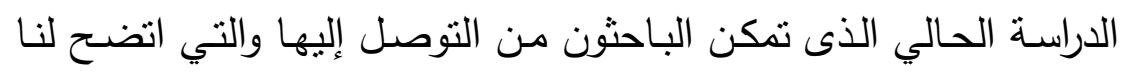

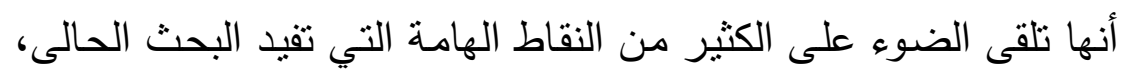

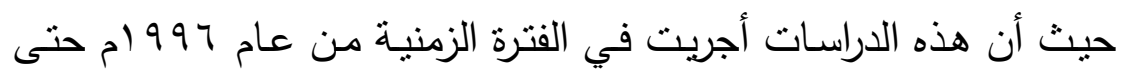

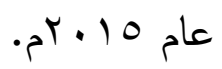

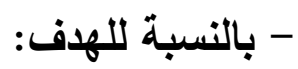

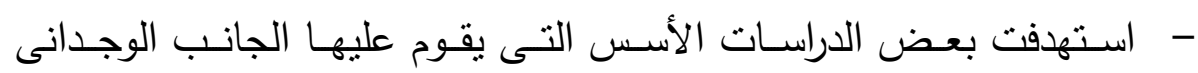

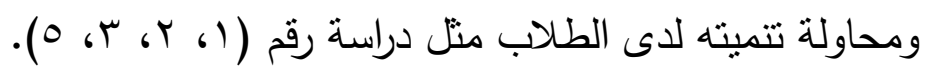
- استهدفت بعض الدراسـات التعرف على القيم التربويـة لطلاب كلية التربيـة

$$
\text { الرياضية مثل دراسة رقم(ع) ). }
$$

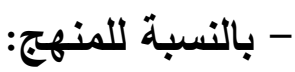
مجلة اسيوط لعلوم وفنون التربية الرياضية 
ولــلك اسـتخدم البـاحثنون المـنهج الوصـفى بأسـلوب (الدراسـات

المسحية) متفقين مع الدراسات السابقة.

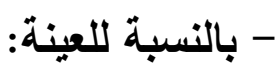

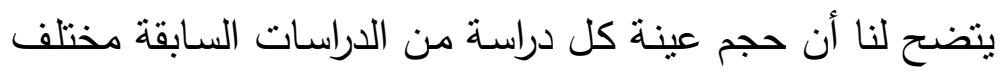

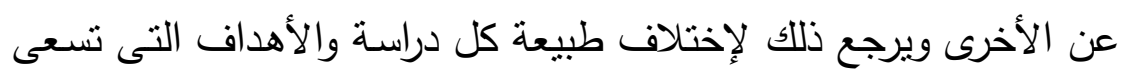

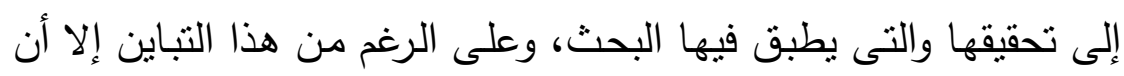
معظم الدراسات السابقة تم إختيار عينة البحث من الفئات الآتية: - خبراء فى مجال علم النفس.

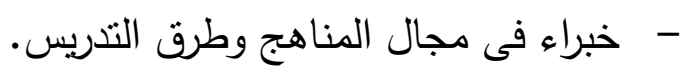
- - طلاب الجامعة بوجه عام وطلاب كلية التربية الرياضية بوجه خاص. - بالنسبة لأدوات جمع البيانات:

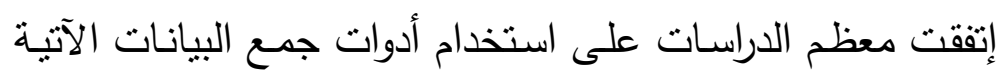

(المقابلة الثخصية، إستمارات الإستبيان).

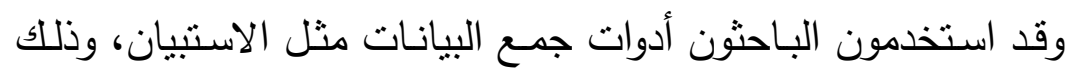
لكناسبته لطبيعة الدراسة.

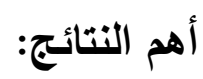
تنوعت نتائج الدراسات السابقة فيما يلي:

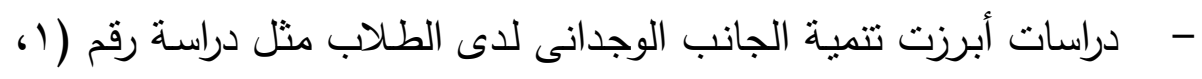

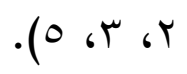

- دراسات أبرزت القيم التربوية للطلاب وعلاقتها بممارسة الأنشطة الرياضية

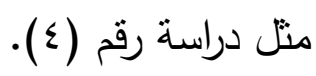

أوجه الاستفادة من الدراسات السابقة: في ضوء العرض السابق للاراسات استفادت الباحثون بما يلى: مجلة أسيوط لعلوم وفنون التربية الرياضية بلية 


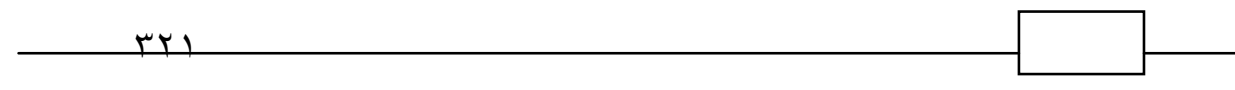

- - تحديد الهدف بما يتلاعم مع ظروف الدراسة.

- - تحديد المنهج المناسب والملائم لطبيعة الدراسة.

- تحديد العينة الني تتتاسب مع طبيعة الدراسة.

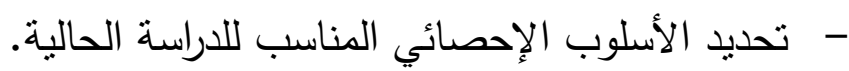

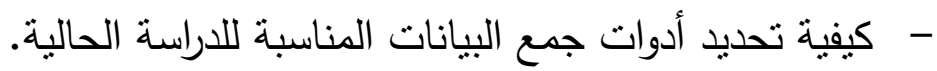

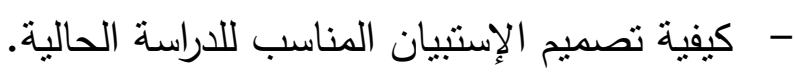

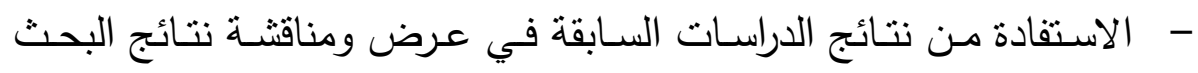

$$
\text { خطة وإجراءات البحث }
$$

استخدم الباحثن الدنهج الوصفى القائم على (الدراسات المسحية)، وذللك لملائمته لطبيعة وظروف البحث.

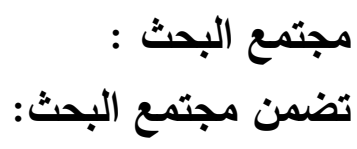

- خبراء فى مجال المناهج وطرق تدريس التربية الرياضية. - - - خبراء في مجال علم النفس. - موجهى ومعلمى التربية الرياضية بالحلقة الثانية من التعليم الأساسى. عينة البحث : ع وجن

تم اختيار عينة البحث بالطريقة العشوائية الطبقية من الفئات التالية: - خبراء فى مجال المناهج وطرق تدريس التربية الرياضية وعددهم (9) -

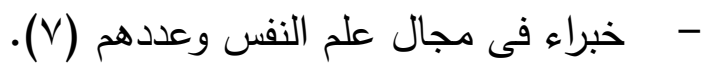

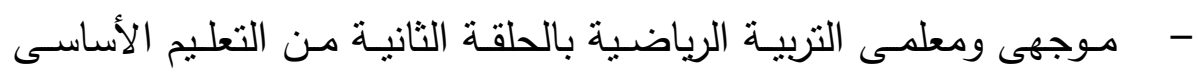

$$
\begin{aligned}
& \text { بمحافظة أسيوط وعددهم (TV) } \\
& \text { أدوات جمع البيانات: } \\
& \text { - إستمارات الإستبيان: }
\end{aligned}
$$

مجلة أسيوط لعلوم وفنون التربية الرياضية 


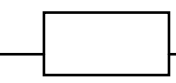

قام الباحثون بتصميم إستمارة إستنيان تهدف إلى التعرف على محددات

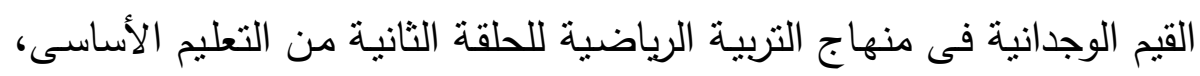
وبعد تحديد الهذف قام الباحثون بالخطوات التالية: 1- تحديد محاور الإستبيان:

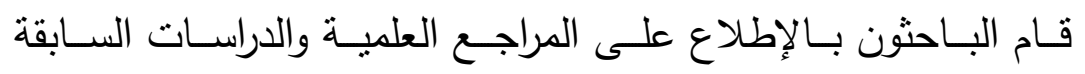

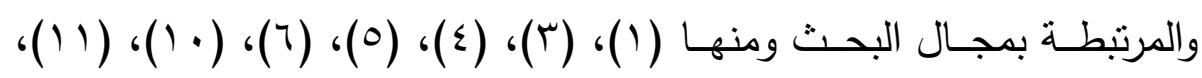

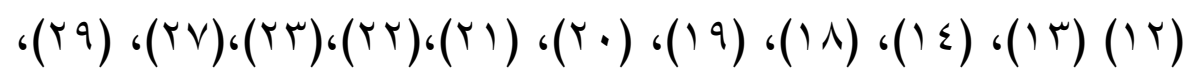

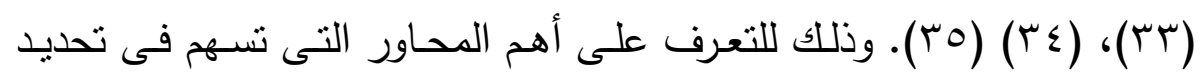

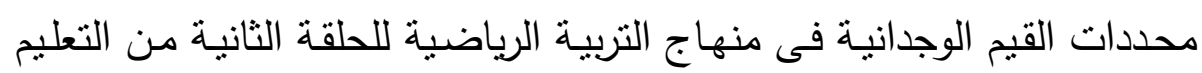
الأساسى وقد أسفر ذلك على تحديد المحاور الآتية:

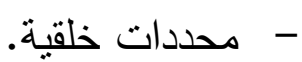
- - محددات نفسية.

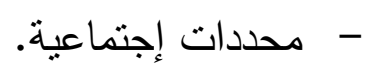
- - محددات صحية.

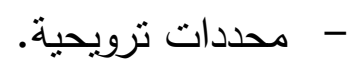
- - محددات تتافسية. r - عرض المحاور على الخبراء:

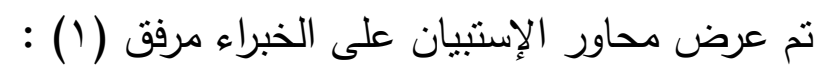

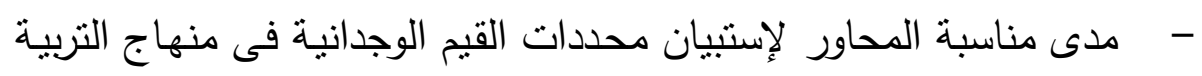

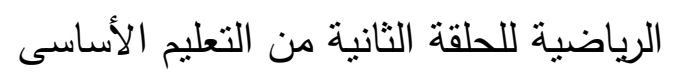

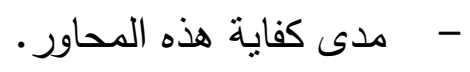
- - تعديل أو حذف أو إضافة محاور أخرى، وجدول (1) - ليوضح ذللك.

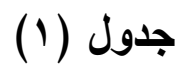
مجلة أسيوط لعلوم وفنون التربية الرياضية 
النسبة المئوية لآراء الخبراء لمحاور محددات القيم الوجدانية فى منهاج

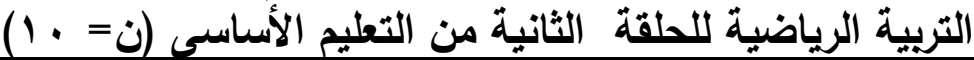

\begin{tabular}{|c|c|c|c|c|}
\hline النسبة المئوية & غير موافق & موافق & المحـــــــاور & 5 \\
\hline$\% 1 \ldots$ & - & 1. & محددات خلقية & 1 \\
\hline$\% 1 \ldots$ & - & 1. & محددات نفسية & $r$ \\
\hline$\% 1 \ldots$ & - & 1. & محددات إجتماعية & $r$ \\
\hline$\% 9$. & 1 & 9 & محددات صحية & $\varepsilon$ \\
\hline$\%$ \%. & $\varepsilon$ & 7 & محددات ترويحية & 0 \\
\hline$\% 0$. & 0 & 0 & محددات تتافسية & 7 \\
\hline
\end{tabular}

يتضـح مـن جـدول (1) أن النسـبة المئويـة لآراء السـادة الخبـراء حـول

المحاور الرئيسية لإستمارة محددات القيم الوجدانية فى منهاج التربية الرياضية للحلقة الثانية من التعليم الأساسى قد تراوحت ما بين ( •0\%: . . . (\%) ولقد إرتضـت الباحثة نسبة مئويـة ( • \% مأكثر مـن آراء السـادة الخبراء للموافقة على المحسور، حيـث تم حذف المحساور التى حصـلت على نسبة أقل مـن $\cdot(\% \vee \cdot)$ وعلى هذا فقد تم التوصل إلى عدد أربعة محاور لإستمارة الإستبيان وهم

كالأتى

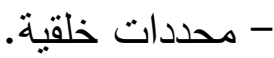
- محددات نفسية. - محددات إجتماعية. - محددات صحية.

ب- إعداد عبـارات إسـتمارة إسـتبيان محددات القيم الوجدانيـة فـى منهـاج التريبة الرياضية للحلقة الثانية من التعليم الأساسى: قام الباحثون بصياغة عبارات كل محور من المحاور السابقة معتمدين

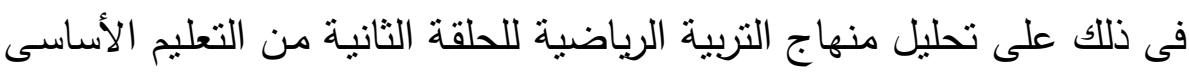
، والمراجع والدراسات المرتبطة والتى تتاولت هذه المحاور ، فقد تضمن محور مجلة أسيوط لعلوم وفنون التربية الرياضية 
المحددات الخلقية (7 1) عبارة، ومحور المحددات النفسية (9 (1) عبارة، ومحور المحددات الإجتماعية (V) عبارات، ومحور الدحددات الصحية (• (1) عبارات.

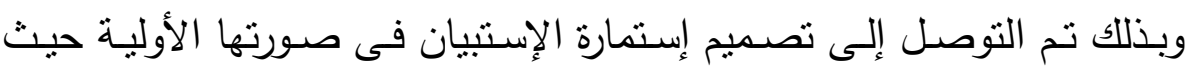
تضمنت (or) عبارة باستخدام ميزان تقدير ثلاثى للعرض على السادة الخبراء

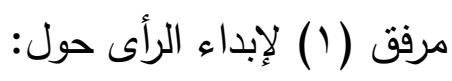

- مدى مناسبة العبارات المقترحة بالنسبة للمحور .

$$
\text { - - إرتباط كل عبارة بالمحور الرئيسى. - }
$$

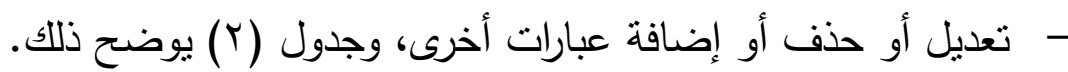

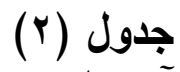

الدرجة المقدرة والنسبة المئوية لآراء الخبراء في العبارات المقترحة لإستبيان

\begin{tabular}{|c|c|c|c|c|c|c|}
\hline \multirow{2}{*}{ المئويةية } & \multirow{2}{*}{ الالدقرة } & \multicolumn{3}{|c|}{ الإستجابات } & \multirow[b]{2}{*}{ العبــــــــــارات } & \multirow[t]{2}{*}{ p } \\
\hline & & موافير & حلى ما & موافق & & \\
\hline & & \multicolumn{5}{|c|}{ المحور الأول : المحددات الخلقية : } \\
\hline$\% \vee\urcorner$ & rی & r & r & 7 & القبم الروحية & 1 \\
\hline$\% 94$ & $\Sigma\rceil$ & 1 & -- & 9 & الولاء والإتتماء & r \\
\hline$\% \wedge$. & $\varepsilon$. & $r$ & 1 & $\mathrm{~V}$ & الطاعة & r \\
\hline$\% 1 \ldots$ & 0 . & -- & -- & 1 . & 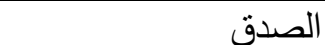 & $\varepsilon$ \\
\hline$\% 97$ & $\varepsilon \wedge$ & -- & 1 & 9 & الأمانة & 0 \\
\hline$\% \vee r$ & דץ & r & 1 & 7 & التسامح & 7 \\
\hline$\% q r$ & $\leq 7$ & 1 & -- & 9 & 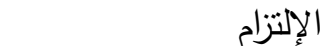 & $\mathrm{v}$ \\
\hline$\%\urcorner \varepsilon$ & re & r & r & $\varepsilon$ & إحترام العمل & $\wedge$ \\
\hline$\%$ \%. & r. & $\varepsilon$ & r & $\varepsilon$ & المحافظة على التقالبد & 9 \\
\hline$\% 07$ & rA & $r$ & 0 & r & الرحمة الرحة & 1. \\
\hline$\%$ \% & rT & r & $r$ & $\varepsilon$ & 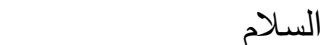 & 11 \\
\hline$\% \wedge \varepsilon$ & $\varepsilon r$ & 1 & r & $\mathrm{V}$ & احترام حقوق الآخرين & Ir \\
\hline
\end{tabular}

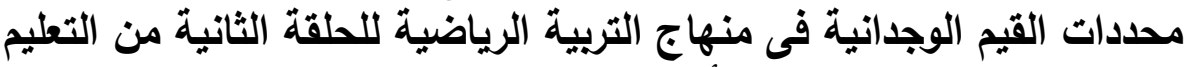

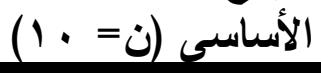

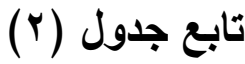

مجلة أسيوط لطلوم وفنون التربية الرياضية 
الدرجة المقدرة والنسبة المئوية لآراء الخبراء فى العبارات المقترحة لإستبيان محددات القيم الوجدانية فى منهاج التربية الرياضية للحلقة الثانية الثية من التيات التعليم الأساسيى (ن = (1)

\begin{tabular}{|c|c|c|c|c|c|c|}
\hline \multirow{2}{*}{ المئوية النسبة } & \multirow{2}{*}{ الألمقدة } & \multicolumn{3}{|c|}{ الإستجابات } & \multirow[b]{2}{*}{ العبــــــــــار ات } & \multirow[t]{2}{*}{ r } \\
\hline & & غوافير & حلى ما & موافق & & \\
\hline$\%$ \%า & rr & $\mu$ & $\bar{r}$ & $\bar{\varepsilon}$ & الحياء & r \\
\hline$\% \wedge$. & $\varepsilon$. & $r$ & 1 & V & العدالة & $1 \varepsilon$ \\
\hline$\% 7$. & r. & $r$ & $\varepsilon$ & $r$ & الوفاء بالوعد & 10 \\
\hline \multirow{2}{*}{$\% \vee 7$} & "ᄉ & $r$ & $r$ & 7 & القدوة الحسنة & 17 \\
\hline & $\varepsilon r$ & 1 & $r$ & $y$ & ر الاتقة الانى : المحددات النفس & المح \\
\hline$\% \curlyvee \wedge$ & rs & r & $r$ & 0 & ضبط النفس & $r$ \\
\hline$\% \vee r$ & ( & $r$ & r & 0 & الدافعية للإنجاز & $\mu$ \\
\hline$\% \wedge$. & $\varepsilon$. & $r$ & 1 & V & الشجاعة & $\varepsilon$ \\
\hline$\% \vee 7$ & ए人 & $r$ & $r$ & 7 & التصمبح & 0 \\
\hline$\% \circ r$ & ry & 0 & r & $\mu$ & الضمير الحي & 7 \\
\hline$\% \wedge$. & $\varepsilon$. & $r$ & 1 & V & الحافز & $\mathrm{V}$ \\
\hline$\% \vee r$ & ry & r & 1 & 7 & تحمل المسؤلبة & $\Lambda$ \\
\hline & & & & & لمحور الثانى : المحددات & تابع \\
\hline$\% 07$ & rᄉ & $\varepsilon$ & $r$ & $\mu$ & الصلابة النفسية & 9 \\
\hline$\% \vee Y$ & דו & $r$ & 1 & 7 & القابلية للإستثارة & 1. \\
\hline$\% \wedge \varepsilon$ & $\varepsilon r$ & $r$ & -- & $\Lambda$ & القيادة & 11 \\
\hline$\% \wedge$. & $\varepsilon$. & 1 & r & 7 & التحكم الإنفعالى & IT \\
\hline$\% 7 \leq$ & r & r & $r$ & $\varepsilon$ & التقبل & r \\
\hline$\% \wedge$. & $\varepsilon$. & $r$ & 1 & V & الروح الرياضية & $1 \varepsilon$ \\
\hline$\% \vee 7$ & r人 & $r$ & r & 7 & التنافس الثريف & 10 \\
\hline$\% \wedge$. & $\varepsilon$. & 1 & r & 7 & الإتجاهات الإيجابية & 17 \\
\hline$\% \wedge \wedge$ & $\varepsilon \varepsilon$ & 1 & 1 & $\Lambda$ & التفوق الرياضى & iv \\
\hline$\% 71$ & T纟 & $r$ & r & 0 & مظاهر الإنتباه & 11 \\
\hline$\% \wedge \varepsilon$ & $\varepsilon r$ & 1 & $r$ & V & الميول والحاجات & 19 \\
\hline
\end{tabular}

تابع جدول (r) (r) (ب)

مجلة أسيوط لعلوم وفنون التربية الرياضية 
الارجة المقدرة والنسبة المئوية لآراء الخبراء فى العبارات المقترحة لإستبيان محددات القيم الوجدانية فى منهاج التربية الرياضية للحلقة الثانية الثية من التيات التعليم الأساسيى (ن = (1)

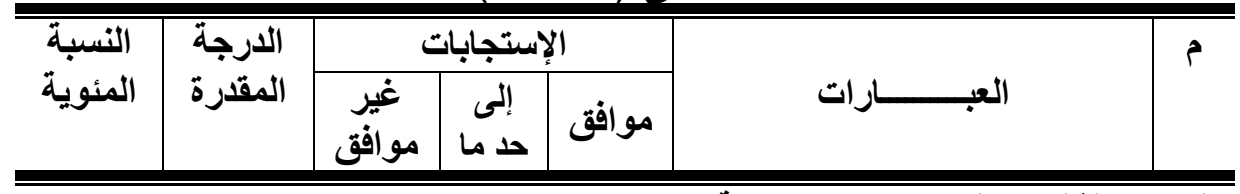

المحور الثالث : المحددات الإجتماعية :

\begin{tabular}{|c|c|c|c|c|c|c|}
\hline$\% \wedge$. & $\varepsilon$. & r & 1 & V & مهارات التواصل & 1 \\
\hline$\%$ \% & $\Gamma \varepsilon$ & $r$ & r & 0 & مهارات التأييد والمساندة & r \\
\hline$\%$ \% & r & r & $\varepsilon$ & $\varepsilon$ & التعاطف & r \\
\hline$\% 94$ & $\leqslant 7$ & 1 & -- & 9 & التعاون مع الآخرين & $\varepsilon$ \\
\hline$\% 97$ & $\Sigma \wedge$ & -- & 1 & 9 & المشاركة الإيجابية & 0 \\
\hline$\% 4$. & r. & $\varepsilon$ & 1 & 0 & السلوك اللفظى & 7 \\
\hline$\% \circ r$ & r & 0 & r & r & السلوك غير اللفظي & $\mathrm{v}$ \\
\hline
\end{tabular}

المحور الرابع : المحددات الصحية :

\begin{tabular}{|c|c|c|c|c|c|c|}
\hline$\% \wedge \varepsilon$ & $\leqslant Y$ & 1 & r & V & العناية بالقوام & 1 \\
\hline$\% \vee 7$ & rᄉ & $r$ & r & 7 & الوقاية من الأمراض & $r$ \\
\hline$\% \wedge \varepsilon$ & $\varepsilon r$ & $r$ & -- & $\Lambda$ & الوعى الصحى السليم & r \\
\hline$\% \vee r$ & ry & $r$ & 1 & 7 & الصحة العامة للجسم & $\varepsilon$ \\
\hline$\%$ \% & r & r & $\mu$ & $\varepsilon$ & الإصابات الرياضية & 0 \\
\hline$\% \wedge \varepsilon$ & $\leqslant Y$ & 1 & $r$ & V & التخذية السليمة & 7 \\
\hline$\% 94$ & $\leqslant 7$ & 1 & -- & 9 & النظافة & V \\
\hline \%ч. & $r$. & $\varepsilon$ & r & $\varepsilon$ & التربية الصحية & $\wedge$ \\
\hline$\% 94$ & $\leqslant 7$ & -- & r & $\wedge$ & العادات الصحية السليمة & 9 \\
\hline$\% 7$. & r. & $\varepsilon$ & r & $\varepsilon$ & الإنحرافات القوامية & 1 . \\
\hline
\end{tabular}

يتضـح مـن جـدول (Y) أن النسـبة المئويـة لآراء السـادة الخبـراء حـول

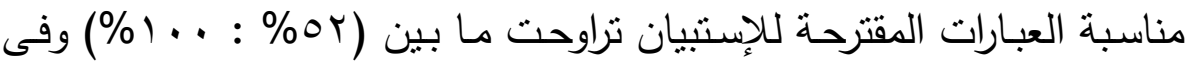
ضوء ذلك إرتضت الباحثة نسبة موافقة ( • \% أكثر لقبول العبارة، وبذللك تم إستبعاد العبـارات التى حصـت على نسبة أقل مـن ( • \% ) بنـاءاً على آراء السـادة الخبراء ومرفق (ع) يوضـح ذلك، وقد تم حذف العبارات رقم (^، 9، مجلة أسيوط لعلوم وفنون التربية الرياضية 


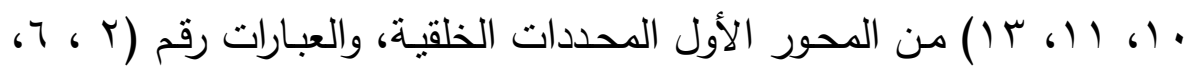

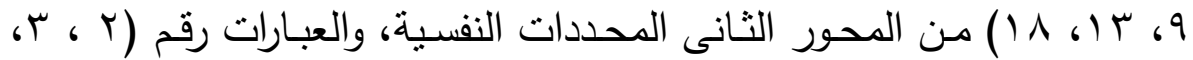

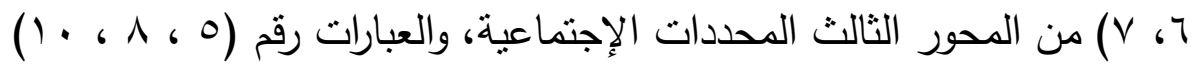
من المحور الرابع المحددات الصحية. المعـاملات العلميـة لإســمارة محـددات القـيم الوجداتيـة فـى منهــاج التربيـة الرياضية للحلقة الثانية من التعليم الأساسى :

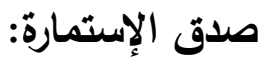

اسـتخدم البـاحثون صــدق الإتسـاق الـداخلى لحسـاب معامـل الصـــق للإستبيان وذلك بهدف التحقق من صدق إستمارة الإستبيان، حيث تم تطبيق الإستبيان على مجموعة قوامها (• (1) من مجتمع البحث ولكن من خارج عينة البحث الأساسية، وذلك لحساب معامل الإزتباط بين درجة كل عبارة بالمحور والمجموع الكلى لـه وكذللك بـين درجـات المحاور والمجموع الكلى للإسـتمارة وجدول (r) يوضح ذللك.

\section{جدول (ب) (ب)}

معاملات الإرتباط بين درجة كل عبارة من عبارات الإستبيان الخاص بمحددات

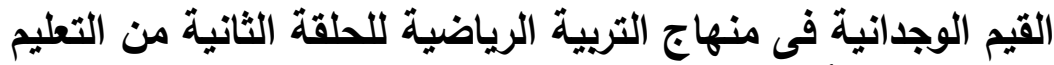

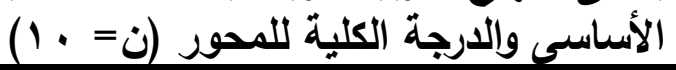

\begin{tabular}{|c|c|c|c|c|c|c|c|c|c|c|c|c|c|c|c|}
\hline \multicolumn{4}{|c|}{ المحور الرابع (المحددات } & \multicolumn{4}{|c|}{ المحور الثالث (المحددات } & \multicolumn{4}{|c|}{ المحور الثاني (المحددات } & \multicolumn{4}{|c|}{ المحسـور الأول(المحددات } \\
\hline $\begin{array}{l}\text { قيمة } \\
\text { (ر) }\end{array}$ & $\varepsilon$ & س & p & قيمة & $\varepsilon$ & س & e & $\begin{array}{l}\text { قيمة } \\
\text { (ر) }\end{array}$ & $\varepsilon$ & س & p & $\begin{array}{l}\text { قيمة } \\
\text { (ر) }\end{array}$ & $\varepsilon$ & س & p \\
\hline .941 & $1 . r \varepsilon$ & $\varepsilon . \varepsilon$ & 1 & $\cdot . \wedge \cdot 1$ & .997 & $\varepsilon . \varepsilon$ & 1 & .911 & $1 . r 7$ & $\varepsilon .7$ & 1 &.$A \vee \varepsilon$ & $1 . r 9$ & $\varepsilon . Y$ & 1 \\
\hline . . 10r & $1 . r 9$ & $\varepsilon . r$ & $r$ & .941 & $1 . r \varepsilon$ & $\varepsilon . \varepsilon$ & $r$ &.$\vee v 79$ & 1.21 & $\varepsilon_{.}$. & $r$ & .9 .4 & $1 . r 9$ & $\varepsilon . Y$ & r \\
\hline$\cdot 7 \cdot 1$ &.$\wedge \varepsilon$ & \&.7 & $r$ & $0.9 \leqslant V$ & 1.79 & $\varepsilon \ldots$ & $r$ & .9 .4 & $1 . r \varepsilon$ & $\varepsilon . \varepsilon$ & $r$ & . AVT & $1 . r \varepsilon$ & $\varepsilon . \varepsilon$ & $r$ \\
\hline$\cdot .9 \vee \wedge$ & 1.57 & $\varepsilon .7$ & $\varepsilon$ & & & & &.$\wedge r \varepsilon$ & $1 . r 9$ & $\varepsilon . Y$ & $\varepsilon$ & .1990 & $1 . r \varepsilon$ & $\varepsilon . \varepsilon$ & $\varepsilon$ \\
\hline. $.9 \vee \wedge$ & 1.57 & $\{.7$ & 。 & & & & & .9 .4 & $1 . r \varepsilon$ & $\varepsilon . \varepsilon$ & 。 & $\therefore \vee .0$ & 1.71 & $\varepsilon . r$ & 。 \\
\hline
\end{tabular}

$$
\text { تابع جدول (r) }
$$


معاملات الإرتباط بين درجة كل عبارة من عبارات الإستبيان الخاص بمحددات

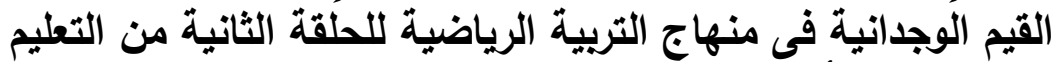

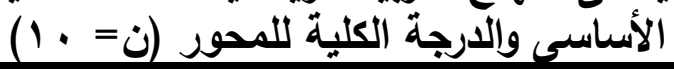

\begin{tabular}{|c|c|c|c|c|c|c|c|c|c|c|c|c|c|c|c|}
\hline \multicolumn{4}{|c|}{ المحور الرابع (المحددات } & \multicolumn{4}{|c|}{$\begin{array}{c}\text { المحور الثالث (المحدداتة } \\
\text { الاجتماعية) }\end{array}$} & \multicolumn{4}{|c|}{ المحور الثاني (المحددات } & \multicolumn{4}{|c|}{ المحسـور الأول(المحددات } \\
\hline $\begin{array}{l}\text { قيمة } \\
\text { (ر) }\end{array}$ & $\varepsilon$ & س & e & $\begin{array}{l}\text { قيمة } \\
\text { (ر) }\end{array}$ & $\varepsilon$ & س & p & قيمة & $\varepsilon$ & س & p & $\begin{array}{l}\text { قيمة } \\
\text { (ر) }\end{array}$ & $\varepsilon$ & س & p \\
\hline$\therefore v \varepsilon$. & 1.71 & $\varepsilon . Y$ & 7 & & & & & .991 & $1 . r 4$ & $\varepsilon .7$ & 7 & .100. & 1.49 & $\varepsilon . r$ & 7 \\
\hline \multirow[t]{8}{*}{. AvQ } & $1 . r \varepsilon$ & $\varepsilon . \varepsilon$ & V & & & & &..$\backslash \Lambda \varepsilon$ & $1 . r 9$ & r.A & v & . Av. & $1 . r \varepsilon$ & $\varepsilon . \varepsilon$ & v \\
\hline & & & & & & & &..$q \cdot r$ & $1 . r \varepsilon$ & ६. & $\Lambda$ &.$\Lambda V \varepsilon$ & 1.49 & E.Y & $\wedge$ \\
\hline & & & & & & & &. .911 & $1 . r 4$ & $\{.7$ & 9 & $.9 \varepsilon<0$ & $1 . r \varepsilon$ & $\varepsilon . \varepsilon$ & 9 \\
\hline & & & & & & & & .9111 & 1.57 & 纟.7 & 1. & .981 & 1.17 & 纟.7 & 1. \\
\hline & & & & & & & &. . 10r & $1 . r 9$ & $\varepsilon . Y$ & 11 & $. .9 \times 1$ & $1 . r 7$ & \&.7 & 11 \\
\hline & & & & & & & & $\therefore . q \cdot r$ & $1 . r \varepsilon$ & $\varepsilon . \varepsilon$ & ir & & & & \\
\hline & & & & & & & & $\cdot . \Lambda \cdot v$ & $1 . \leqslant 1$ & $\varepsilon \ldots$ & $1 \pi$ & & & & \\
\hline & & & & & & & & $\cdot . \wedge \cdot v$ & $1 . \leqslant 1$ & $\varepsilon \ldots$ & $1 \varepsilon$ & & & & \\
\hline
\end{tabular}

$$
\text { قيمة (ر) الجدولية عند مستوى معنوية (0 . . . ) . . . }
$$

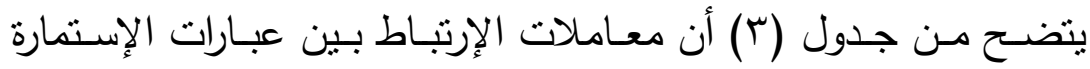

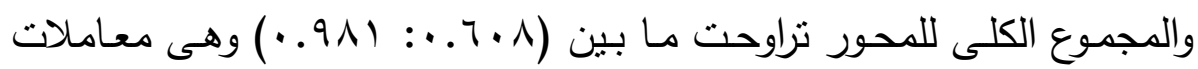

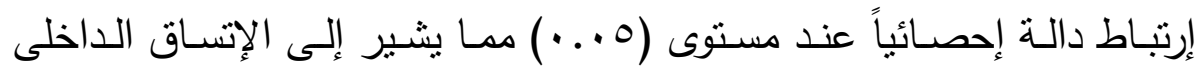

لإلستمارة.

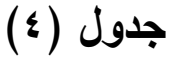

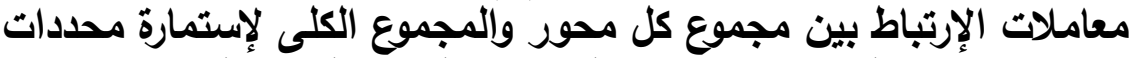

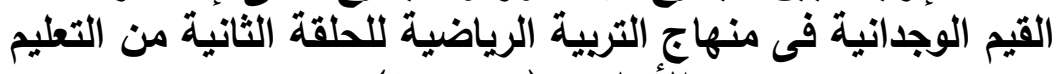

\begin{tabular}{|c|c|c|c|c|}
\hline قيمة (ر) & الإنحراف المعيارى & المتوسط الحسابي & المحــــــاور & r \\
\hline. .991 & א.r & $\varepsilon \vee . \wedge$ & المحددات الخلقية & 1 \\
\hline$\because .9 \wedge \wedge$ & 17.01 & $7 \cdot . r$ & المحددات النفسية & r \\
\hline$\cdot \lambda \cdot \mu$ & r.A9 & IY.A & المحددات الإجتماعية & $r$ \\
\hline .9990 & $V .97$ & $\mu . r$ & الصحددات الصحية & $\varepsilon$ \\
\hline
\end{tabular}

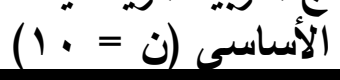


بتضـح مـن جدول (ع) أن معـاملات الإرتبـاط بين مجهوع كل محور

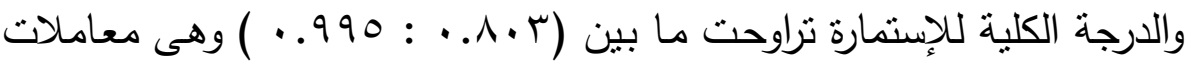

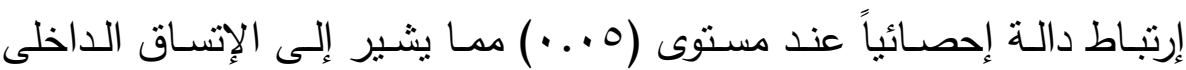

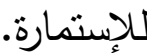

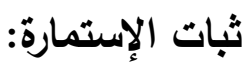

استخدم البـاحثون طريقة الإختبـار وإعـادة الإختبـار لحسـاب معاملـل الثبات لإستمارة الإستبيان حيث قام الباحثون بنطبيق الإستمارة على مجموعة

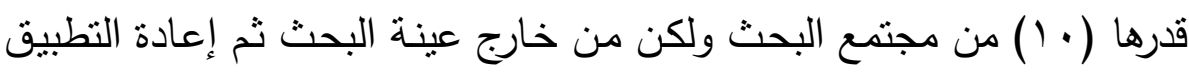

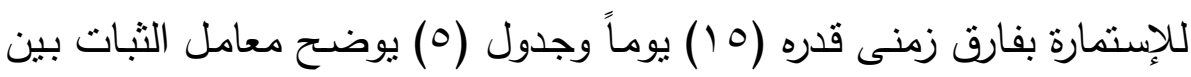

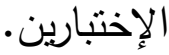

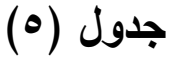

معاملات الإرتباط بين الإختبار الأول والثانى لمحاور إستبيان محددات القيم الوجدانية في منهاج التربية الرياضية للحلقة الثانية من التعليم الأساسى (ن = - 1)

\begin{tabular}{|c|c|c|c|c|c|c|}
\hline \multirow{2}{*}{ قيمة } & \multicolumn{2}{|c|}{ الإختبار الثانى } & \multicolumn{2}{|c|}{ الإختبار الأول } & \multirow{2}{*}{ المحـــــاور } & \\
\hline & انحراف & متوسط & ان انحراف & 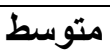 & & \\
\hline. .991 & Ir.r. & $\sum \vee . T$ & IT.rK & $\varepsilon \vee . \varepsilon$ & المحددات الخلقية & \\
\hline. .994 & 17.71 & $7 . .7$ & $17 . \Sigma 9$ & $7 \ldots$ & 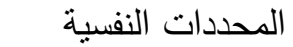 & \\
\hline $.9 \mathrm{VI}$ & r.OV & Tr.T & $T .74$ & $14 \ldots$ & المحددات الإجتماعية & r \\
\hline. $.9 \wedge \mathrm{V}$ & $\vee .91$ & r.. & $\lambda_{\ldots} .$. & $r \ldots$ & المحددات الصحية & $\varepsilon$ \\
\hline. .994 & r9.А9 & 10r.A & r9.人1 & $101 . \varepsilon$ & الإستمارة ككل & \\
\hline
\end{tabular}

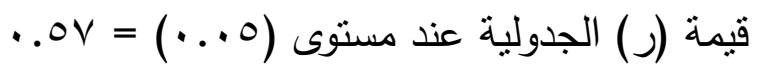

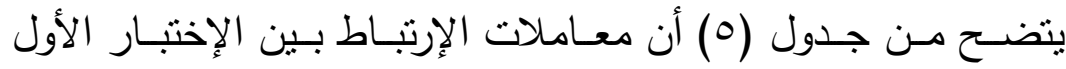

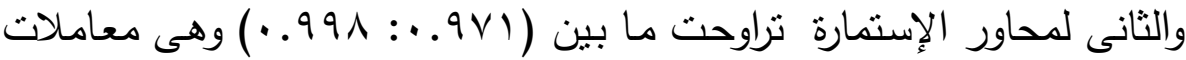
إرتباط دالة إحصائياً عند مستوى (0. . •) مما يشير إلى ثنات الإستمارة. 
بعد إتمـام المعـاملات العلميـة لإسـمارة محددات القيم الوجدانيـة فى منهاج التربية الرباضية للحلقة الثانية من التعليم الأساسى، قام الباحث بتطبيق الإسـتبيان على عينـة البحثث مـن الخبـراء فى مجـال علم الـفس، والمنـاهج وتدريس التربية الرياضية وموجهي ومعلمى التربية الرياضية خلال الفترة من من

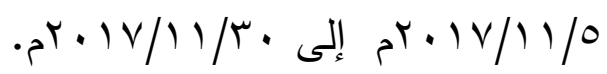

$$
\begin{aligned}
& \text { المعالجات الإحصائية: }
\end{aligned}
$$

تم إجراء المعالجات الإحصائية باستخدام الأساليب الإحصائية التالية:

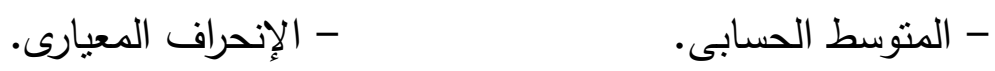

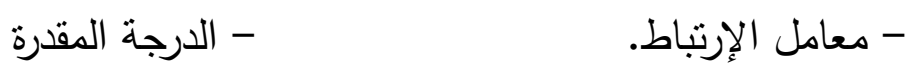

$$
\begin{aligned}
& \text { - النسبة المئوبية. }
\end{aligned}
$$

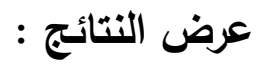

تحقيقاً لهدف البحث وفى حدود ما توصل إليه الباحثون من معلومات وبيانات

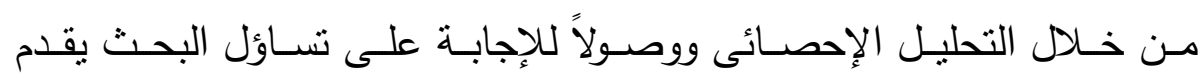

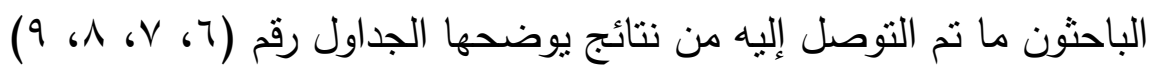

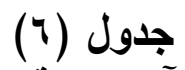

\begin{tabular}{|c|c|c|c|c|c|c|}
\hline \multirow{2}{*}{ المئوية النسبة } & \multirow{2}{*}{ المقرجة } & \multicolumn{3}{|c|}{ الإستجابات } & \multirow[b]{2}{*}{ العبـــــــــــارات } & \multirow[b]{2}{*}{ r } \\
\hline & & غير & إلى حد & موافق & & \\
\hline$\% \wedge \wedge . r q$ & 180 & r & $1 \leq$ & ry & القيم الروحبة & 1 \\
\hline$\% 94.00$ & 199 & 1 & 7 & ד ب & الولاء والإنتماء & r \\
\hline$\% \wedge 0.11$ & IN & $\varepsilon$ & $\wedge$ & ו & الطاعة & $r$ \\
\hline$\% 97 . \mathrm{YV}$ & $r \cdot V$ & 1 & r & $\varepsilon$. & الصدق & $\varepsilon$ \\
\hline$\% 90.1 \varepsilon$ & r.o & -- & 0 & بر & الأمانة & 0 \\
\hline \%人r.Yo & 189 & $\varepsilon$ & 1. & rq & التشامح & 7 \\
\hline
\end{tabular}

الارجة المقدرة والنسبة المئوية لآراء عينة البحث فيما يتعلق بالمحور الأول

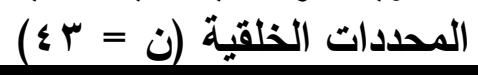

$$
\text { تابع جدول (†) }
$$


الدرجة المقدرة والنسبة المئوية لآراء عينة البحث فيما يتعلق بالمحور الأول

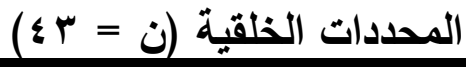

\begin{tabular}{|c|c|c|c|c|c|c|}
\hline \multirow{2}{*}{ المئوية النسبة } & \multirow{2}{*}{ المقرجة } & \multicolumn{3}{|c|}{ الإستجابات } & \multirow[b]{2}{*}{ العبـــــــــارات } & \multirow[b]{2}{*}{ r } \\
\hline & & مو أفير & إلى حـ حد & موافق & & \\
\hline 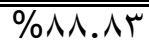 & 191 & $r$ & 7 & T & الإلتزام & V \\
\hline$\% 91.74$ & $19 V$ & 1 & V & ro & احترام حقوق الآخرين & $\Lambda$ \\
\hline$\% \wedge \varepsilon .1 \wedge$ & 111 & 0 & V & $\mu_{1}$ & العدالة & 9 \\
\hline$\% \wedge \neg . . \leq$ & 110 & $\varepsilon$ & V & rr & الوفاء بالوعد & 1. \\
\hline$\% 9 \cdot .79$ & 190 & r & 7 & م & القدوة الحسنة & 11 \\
\hline
\end{tabular}

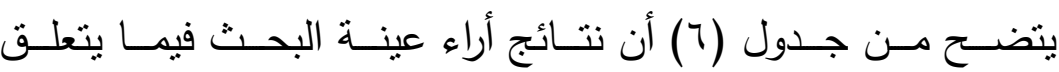

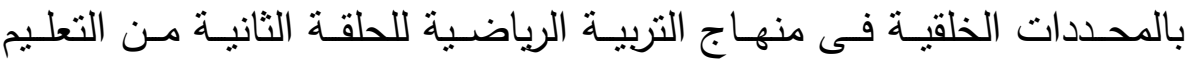

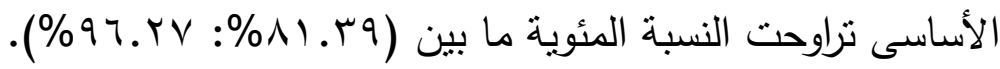

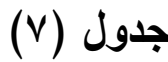

الارجة المقدرة والنسبة المئوية لآراء عينة البحث فيما يتعلق بالمحور الثانى (لآل

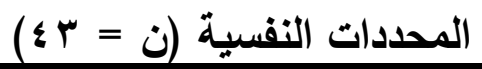

\begin{tabular}{|c|c|c|c|c|c|c|}
\hline \multirow{2}{*}{ المئوية } & \multirow{2}{*}{ اللدقرة } & \multicolumn{3}{|c|}{ الإستجابات } & \multirow[b]{2}{*}{ العبـــــــــارات } & \multirow[t]{2}{*}{ s } \\
\hline & & مو افيّ & إلى حـ & مو افق & & \\
\hline \%97.YV & T.V & 1 & $r$ & $\varepsilon$. & التقة بالنفس & 1 \\
\hline$\% \wedge 7.9 \vee$ & $1 / \mathrm{V}$ & $\bar{r}$ & 1. & Tा & الدافعية للإنجاز & $T$ \\
\hline$\% \wedge 9 . \vee 7$ & 195 & $\mu$ & 0 & ro & الشجاعة & $r$ \\
\hline$\% \wedge 0.11$ & $1 \wedge \Gamma$ & $\mu$ & 1. & $r$. & التصميح & $\varepsilon$ \\
\hline \%人ฯ..ร & 110 & $\varepsilon$ & $\mathrm{V}$ & rT & الحافز & 0 \\
\hline$\% \wedge 9 . \vee 7$ & $19 \pi$ & $\varepsilon$ & $r$ & ד & تحمل المسؤلية & 7 \\
\hline$\% \vee \varepsilon . \wedge \wedge$ & 171 & 0 & IV & Tा & القابلية للإستثارة & V \\
\hline$\% 9$ \%.०. & 199 & r & $\varepsilon$ & rV & القيادة & $\Lambda$ \\
\hline$\% \wedge \Lambda . \wedge \mu$ & 191 & 1 & 1. & MY & التحكم الإنفعالى & 9 \\
\hline$\% \wedge \wedge . \wedge \mu$ & 191 & $\mu$ & 7 & $r \varepsilon$ & الروح الرياضية & 1. \\
\hline$\% \wedge 7.9 \vee$ & $1 \wedge V$ & $\varepsilon$ & 7 & $r r$ & التتافس الثريف & 11 \\
\hline$\% \wedge \varepsilon . \mid \wedge$ & 111 & 0 & $\mathrm{~V}$ & 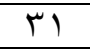 & الإتجاهات الإيجابية & IT \\
\hline$\% \wedge \wedge . \wedge \mu$ & 191 & $r$ & 7 & $r \varepsilon$ & التفوق الرياضى & 11 \\
\hline$\% \wedge 7 . . \varepsilon$ & 110 & $r$ & 9 & W & الميول والحاجات & $1 \varepsilon$ \\
\hline
\end{tabular}


يتضح من جدول (V) أن نتائج أراء عينة البحث فيما يتعلق بالمحددات النفسية فى منهاج التربية الرياضية للحلقة الثانية من التعليم الأساسى تراوحت

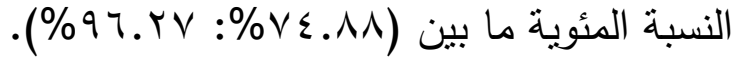

\section{جدول (^)}

الارجة المقدرة والنسبة المئوية لآراء عينة البحث فيما يتعلق بالمحور الثالث

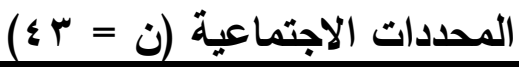

\begin{tabular}{|c|c|c|c|c|c|c|}
\hline \multirow{2}{*}{ المئوية } & \multirow{2}{*}{ المقدرة } & \multicolumn{3}{|c|}{ الإستجابات } & \multirow[b]{2}{*}{ العبـــــــــارات } & \multirow[t]{2}{*}{ ? } \\
\hline & & موافير & إلى حا & موافق & & \\
\hline$\% \wedge 4.9 \vee$ & IAV & r & 1. & ו & مهارات التواصل & 1 \\
\hline$\% 99 . .7$ & YIT & -- & 1 & $\varepsilon r$ & التعاون مع الآخرين & r \\
\hline$\% 90 . r \varepsilon$ & r.o & -- & 0 & rᄉ & المشاركة الإيجابية & $r$ \\
\hline
\end{tabular}

يتضح من جدول (^) أن نتائج أراء عينة البحث فيما يتعلق بالمحددات

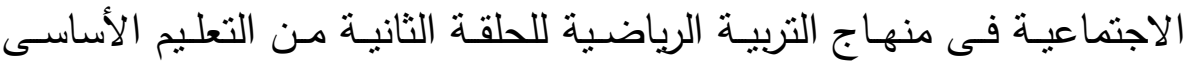

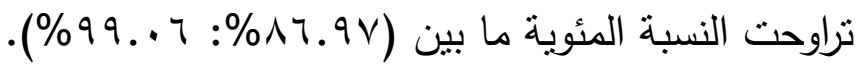
جدول (a)

الارجة المقدرة والنسبة المئوية لآراء عينة البحث فيما يتعلق بالمحور الرابع المحددات الصحية (ن

\begin{tabular}{|c|c|c|c|c|c|c|}
\hline \multirow{2}{*}{ المئوية } & \multirow{2}{*}{ المقرجة } & \multicolumn{3}{|c|}{ الإستجابات } & \multirow[b]{2}{*}{ العبـــــــــارات } & \multirow[t]{2}{*}{ r } \\
\hline & & موافير & إلى حـ مـا & موافق & & \\
\hline 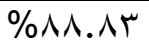 & 191 & 1 & 1. & Tr & العناية بالقوام & 1 \\
\hline \%人r.Yo & 189 & $r$ & ir & rA & الوقاية من الأمراض & $r$ \\
\hline$\% 94.00$ & 199 & r & $\varepsilon$ & rV & الوعى الصحي السلبم & $r$ \\
\hline$\% \wedge 9 . \vee 7$ & $19 \pi$ & $r$ & $\mathrm{~V}$ & $r \varepsilon$ & الصحة العامة للجسم & $\varepsilon$ \\
\hline$\% \wedge \wedge . \wedge \mu$ & 191 & $r$ & $\Lambda$ & Tr & التغذية السليمة & 0 \\
\hline \%qV.r. & $r \cdot 9$ & 1 & 1 & $\leqslant$ & النظافة & 7 \\
\hline$\% 94.00$ & 199 & 1 & 7 & ד & العادات الصحية السليمة & V \\
\hline
\end{tabular}


يتضح من جدول (9) أن نتائج أراء عينة البحث فيما يتعلق بالدحددات

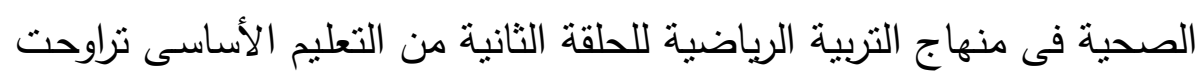

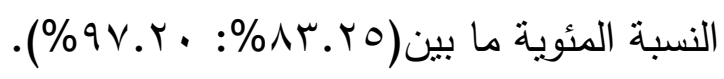

مناقشة النتائج:

تساؤل البحث :

ما محددات القيم الوجدانية فى منهاج التربية الرياضية للحلقة الثانية من

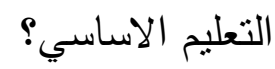

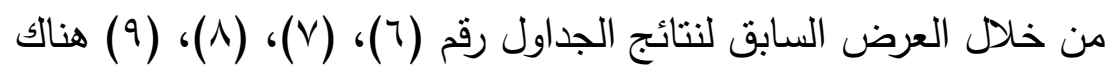

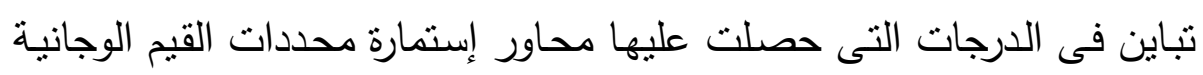

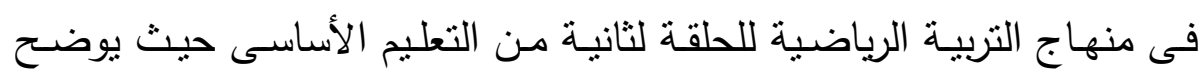

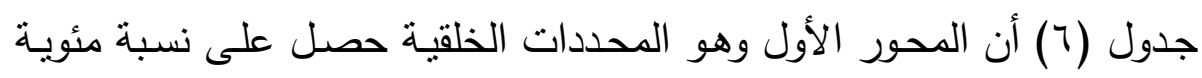

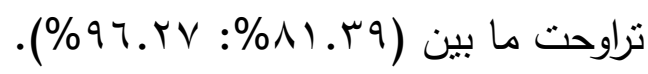
وهى نسبة مرتفعة ندل على مدى أهمية القيم الخلقية كأحد عناصر القيم

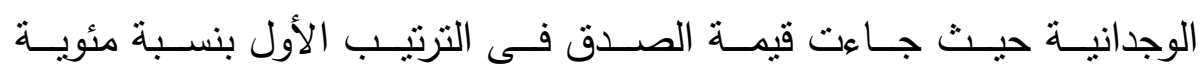

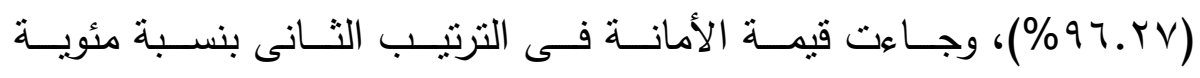

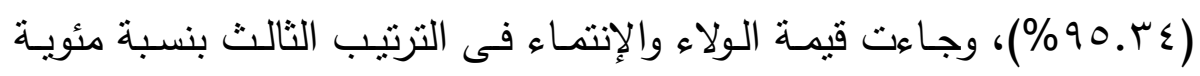

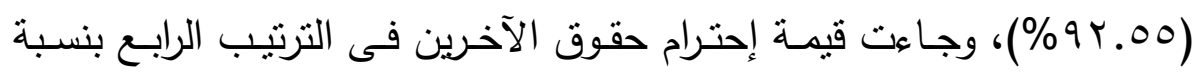

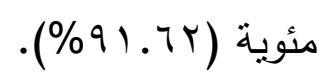

ويعزو الباحثون ذلك الإرتفاع فى النسبة المئوية من آراء عينة البحث إلى الى التى

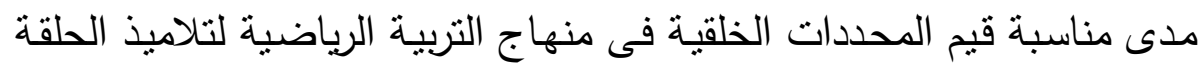

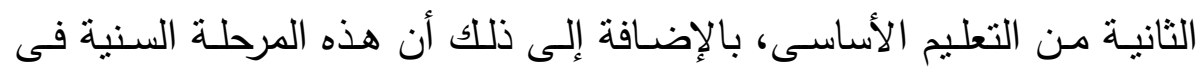

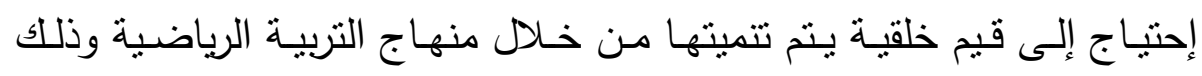
بالوعى المستمر من قبل معلم التربية الرياضية الذى يجب أن يكون قدوة حسنة للتلاميذ. مجلة أسيوط لعلوم وفنون التربية الرياضية 
ويتضح من جدول (V) أن المحور الثانى وهو المحددات النفسية حصل

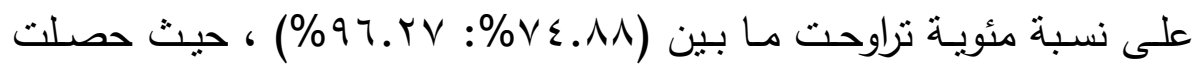

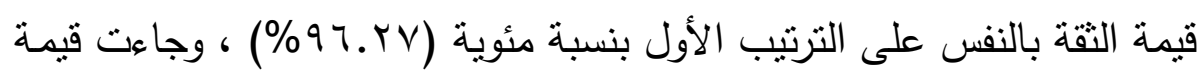

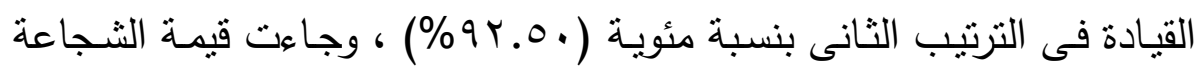

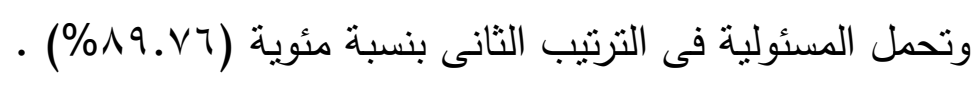

ويعزو الباحثون ذلك الإرتفاع فى النسبة المئويـة إلى مدى أهميـة القيم

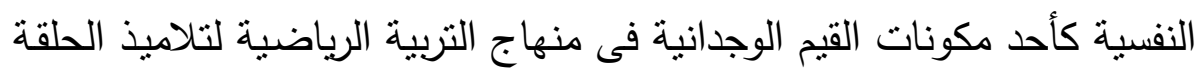

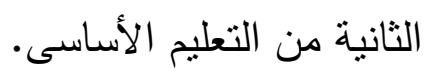

ويوضح جدول (^) أن المحور الثالث وهو الدحدات الإجتماعية حصل

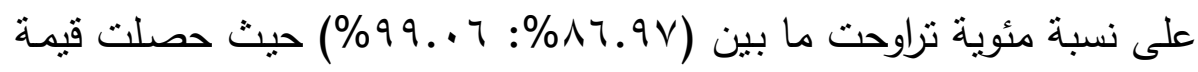

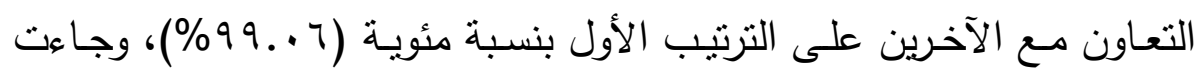

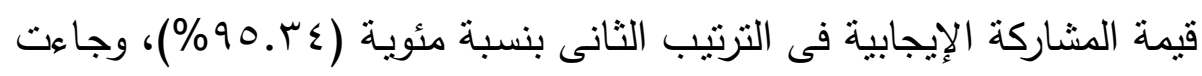

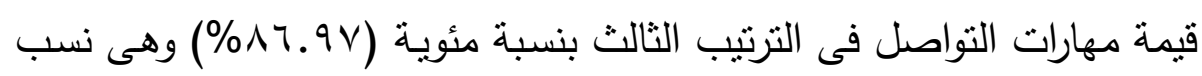
مرتفعة تدل على مدى أهميتها لتلاميذ الحلقة الثانية من التعليم الأساسى.

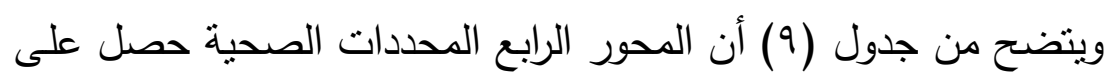

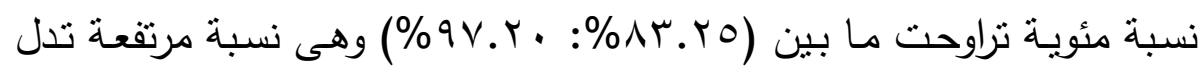

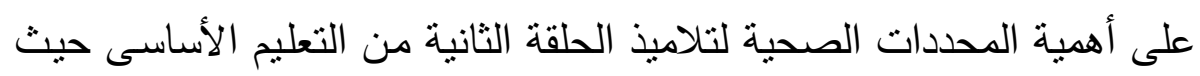

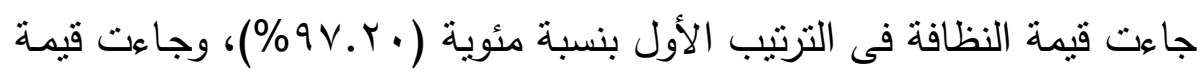

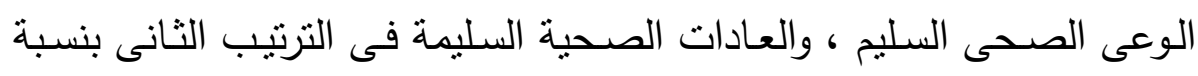

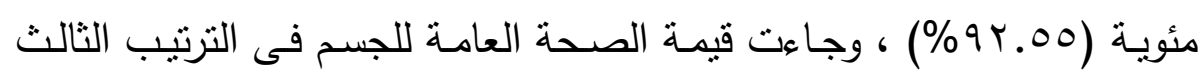

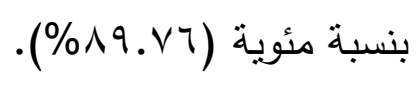

ويرجع الباحثون مدى الإرتفاع فى النسبة المئوية للمحددات الإجتماعية

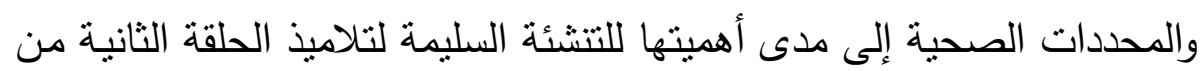

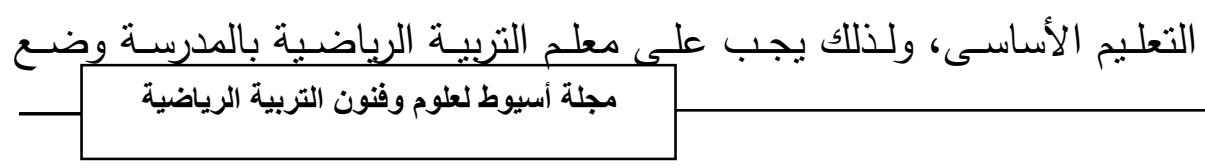


الهـدف الوجـدانى فـى كـل درس بمـا يتتاسـب مـع تتميـة بعض القيم الخلقيـة والنفسية والإجتماعية والصحية.

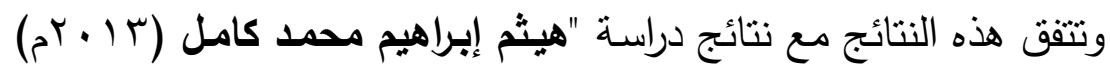

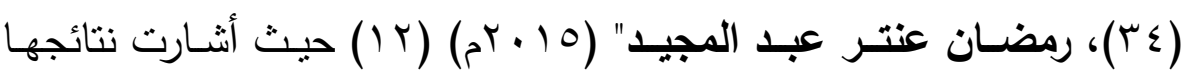

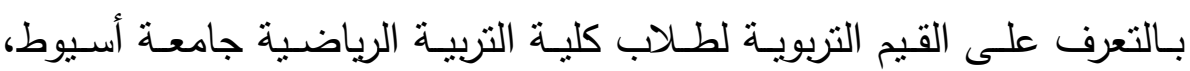
وأوضحت أيضـاً وجود إرتباط قوب بين اكتسـاب القيم التربوبـة وبين ممارسـة الأنشطة الرياضبية. وفى هذا الصدد يثير "محمود عبد الحليم عبد الكريم" (0 ا • بم) أنه

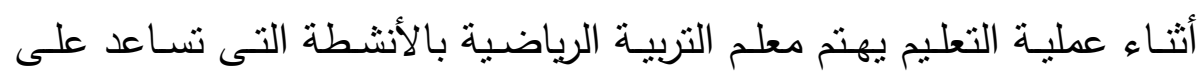
تعديل وتطوير الإتجـاه الإيجـابى نحو التربيـة الرباضية ، وأيضـاً تدعيم القيم

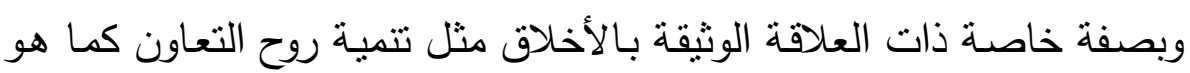

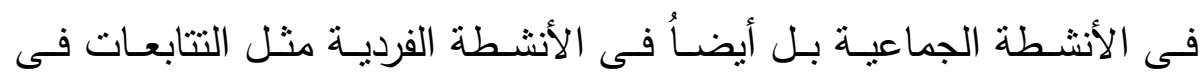

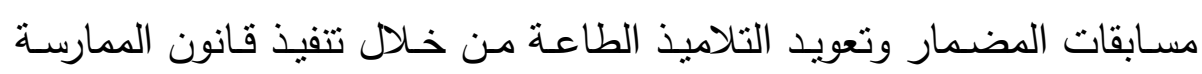

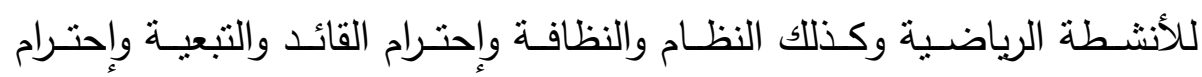

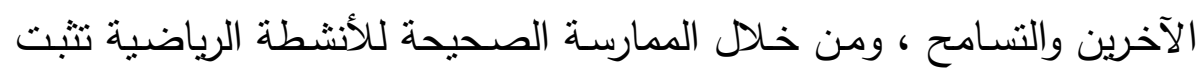
لدى التلاميذ دوافع وحاجات وميول ومثل عليا لها معناها من أجل التفاعل. (r.0: r)

وبهذا يكون الباحثون قد أجابوا على تسـاؤل البحث وهو مـا محددات القيم الوجدانية فى منهاج التربية الرياضية للحلقة الثانية من التعليم الاساسي؟

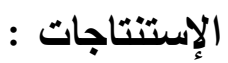
في حدود وطبيعة ومجال البحث والهدف منه وفي ضوء تساؤل البحث والمنهج المستخدم وطبيعة العينة ومن خلال التحليل الإحصائي للبيانات، أمكن ومن ولئ التوصل إلى الاستتناجات التالية: 


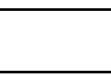

- - - التوصل إلى محددات القيم الوجدانية فى منهاج التربية الرياضية للحلقة الثانية من التعليم الأساسى وهى كالأتى:

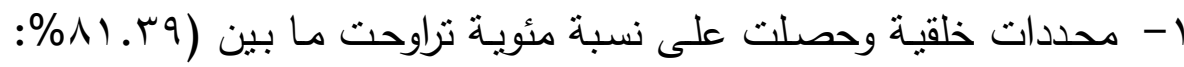

$$
\text { . (\%94.YV }
$$

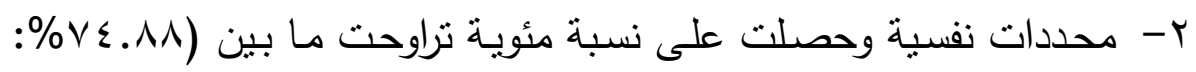

$$
\text { . \%97. rV }
$$

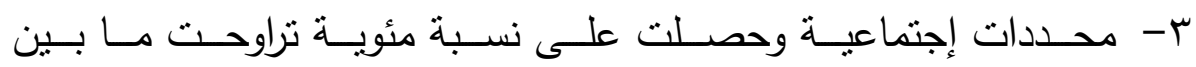

$$
\text { .(\%99.. } 4: \% \wedge 4.9 \vee)
$$

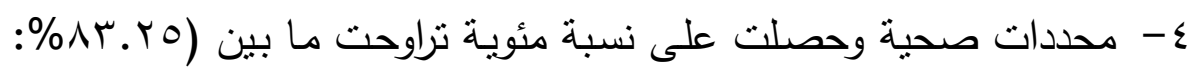

$$
\text { .(\%9V.r. }
$$

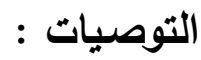

1- الإهتمام من قبل وزارة التربية والتعليم بتبنى وتعميم إستمارة محددات القيم

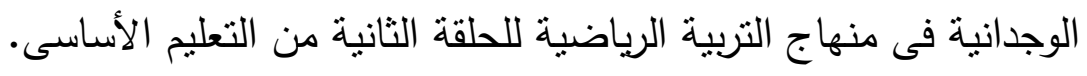

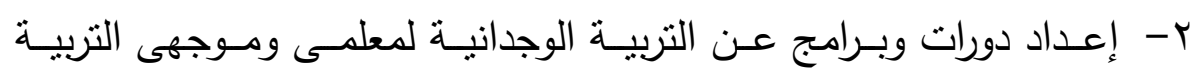

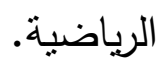

ب- وضـع خطـة مناسبة لتتميـة القيم الوجدانيـة فى المدارس ويقوم بتتفيذها معلمى التربية الرياضية. ؟ - ضرورة توفير كتيب للتلميذ يحتوى على القيم الوجدانية وتعريفاتها وكيفية إكتسابها وتتميتها. 0- إصدار دليل لمعلمى التربية الرياضية لتعريفهم بمهامهم تجاه تتمية القيم الوجدانية من خلال أنشطة التربية الرياضية.

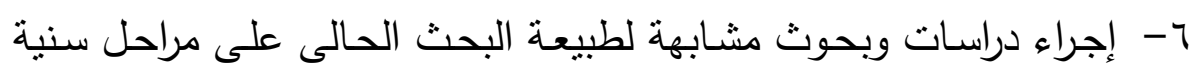
مختلفة.

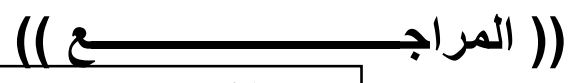




\section{أولاً: المراجع باللفة العربية:}

1 - ابراهيم كاظم العظماوى: معالم من سيكولوجية الطفولة والفتوة والثباب"،

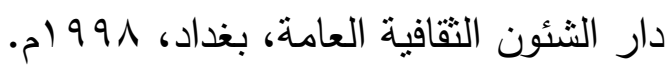

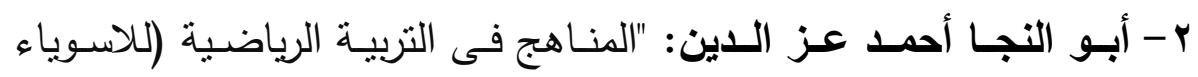

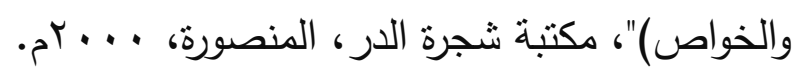

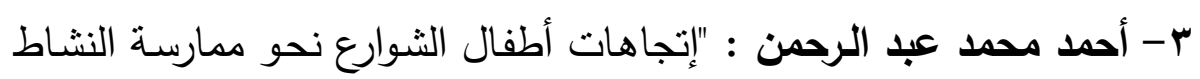
الرياضى"، رسالة ماجيستير ، كلية التربية الرياضية، جامعة الجهابة

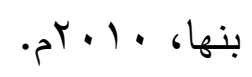

ع - إخـلاص محمــد عبــ الحفـيظ: "التوجيـه والإرشـاد النفسـى فـى المجـال

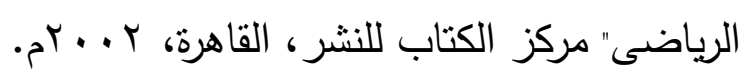

ه - أسـامة كامسل راتب: "علم النفس الرياضـى"، دار الفكر العربى، القاهرة،

$$
\text { . }) 990
$$

צ- أســامة كامـل راتـب : "تدريب المهـارات النفسـية تطبيقـات فـى المجـال

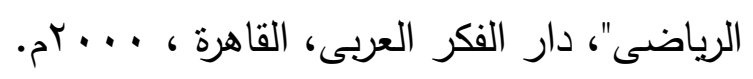

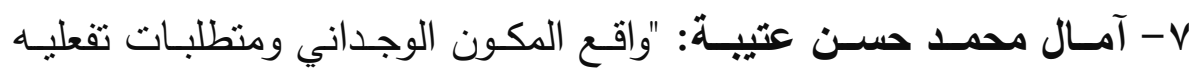
بمنظومـة الإعداد التربوي للمعلم من وجهة نظر الطالبات

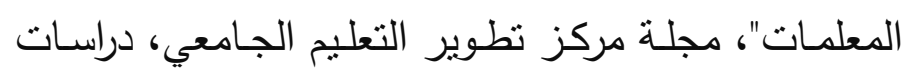

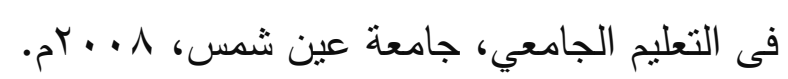

1- أمين أنو الخولى وآخرون: "التربية الرياضية المدرسية دليل معلم الفصل جلئ

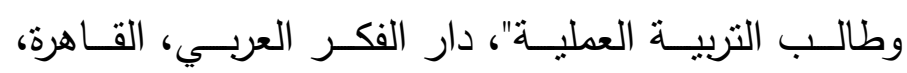

$$
\text { . }) 99 \leq
$$

9 - أمين أنور الخولى، جمال الدين الشافعى: "مناهج التربية البدنية المعاصرة

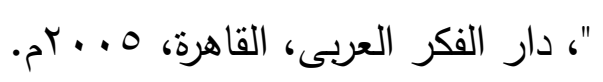

\section{مجلة أسيوط لعلوم وفنون التربية الرياضية}




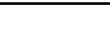

• 1 - تيسير مصلح كوافحة: "علم النفس التربوى تطبيقات فى مجال التربية

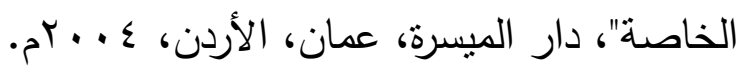

11 - حامد عبد السلام زهران: "علم النفس الإجتماعى أسسه وتطبيقاته"، دار

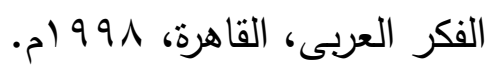

r ا - رضان عنتر عبد المجيد: "القيم التربوية لطلاب كلية التربية الرياضية الترهية

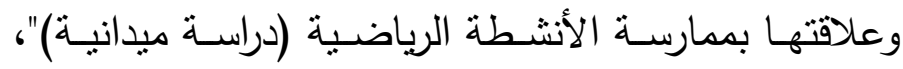

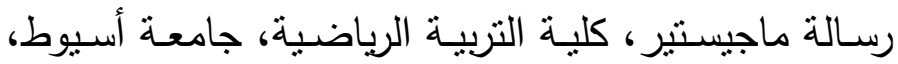

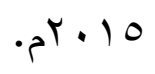

r ا - زين العابدين درويش: "علم النفس الإجتماعى أسسه وتطبيقاته"، دار

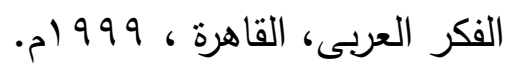

؛ ا - شعبان جاب الله : "علم النفس الإجتماعى أسسه وتطبيقاته"، دار الفكر الفر

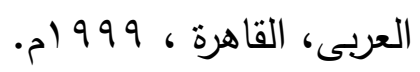

ه - صالح إبراهيم علي: "التربية الوجدانية في الإسلام دراسة تحليلية"، رسالة

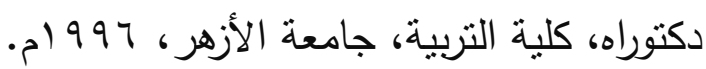

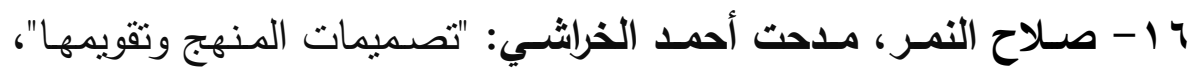

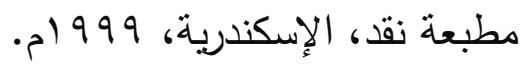

IV - طارق كمال: "أساسيات فى علم النفس العام" ، مؤسسة شباب الجامعة، الإنة

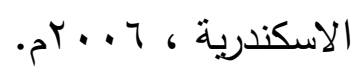

11 - عبـد الـرحمن العيسـوى: "سـيكولوجية النــو (دراســة فـ نمـو الطفل

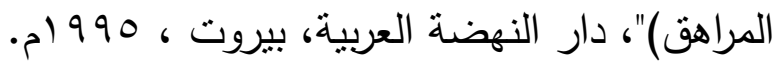

9 1 19

$$
\text { الحديث، الاسكندرية ، } 991 \text { ام. }
$$

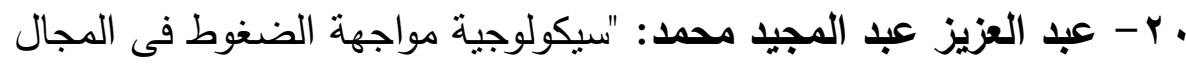

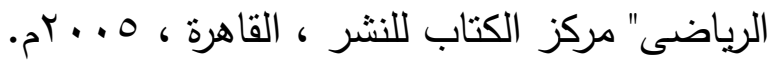


ا Y - عبـد القتــاح محمــ دويـدار: "علم نفس النمـو والارتقـاء"، دار المعرفـة

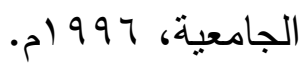

r r - عبد الفتاح محمد دويدار : "علم النفس الإجتماعى أصوله ومبادئه"، دار

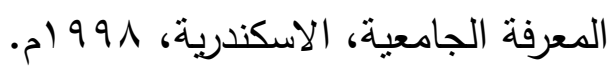

بr - فوأد البهـى السيد، سـعد عبد الرحمن: "علم النفس الإجتمـاعى رؤيـة معاصرة"، دار الفكر العربى، القاهرة، 999 (م.

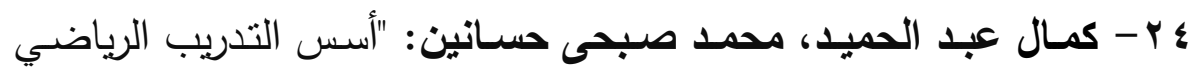

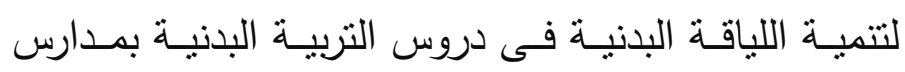

البنين والبنات"، دار الفكر العربي، القاهرة، •99 إم. 99

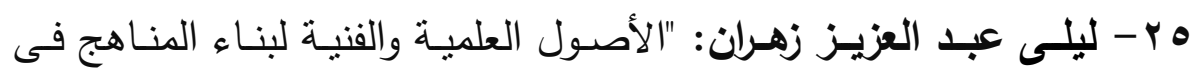

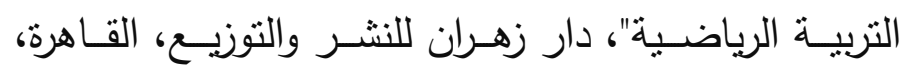

$$
\cdot r^{2} \cdot r
$$

צ ץ - محمـد حسـن عـلاوى: "علـم الـنفس الرياضـى"، ط 9 9، دار المعـارف،

$$
\text { القاهرة، ع } 99 \text { (م. }
$$

rV - محمد حسن عـلاوى، أسـامة كامـل راتب : "البحث العلمى فى التربية

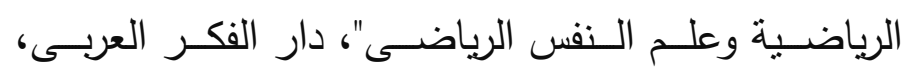

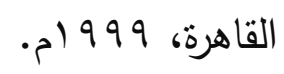

^ ץ - محمد سعيد عزمسى: "أسـاليب تطوير وتتفيذ درس التربية الرياضية فى

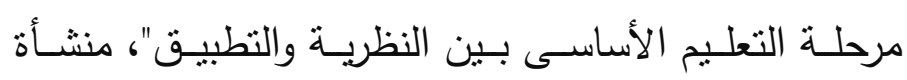

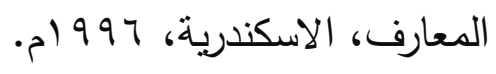

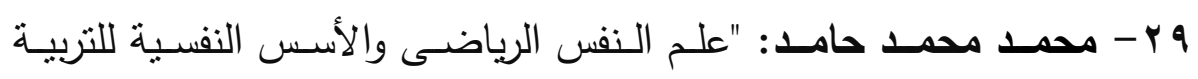

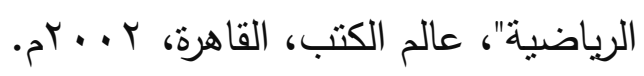

• ץ- محمـود عبد الحليم عبد الكريم: "ديناميكية تدريس التربية الرياضية"،

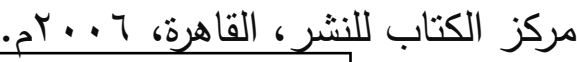




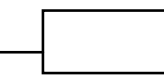

اب- محمـود عبد الحليم عبد الكريم: "منظومـة الرياضـة الددرسية (التعليم

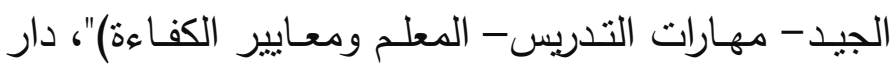

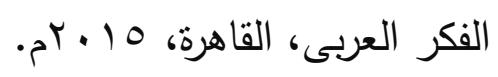

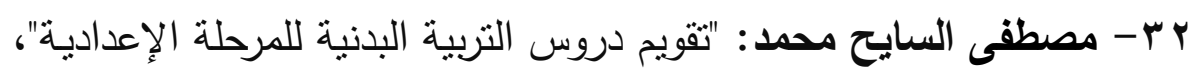

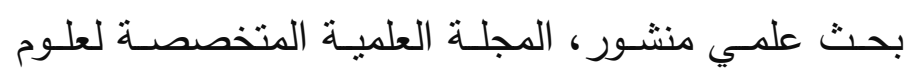

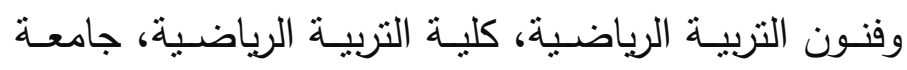

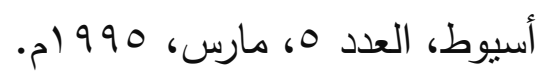

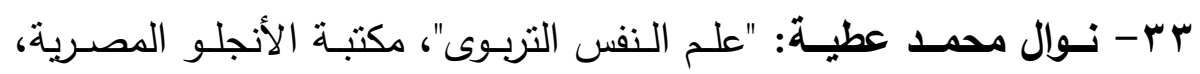

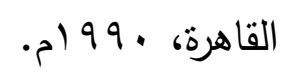

ع س- هيثم ابراهيم محمد: "دور الأنشطة الطلابية فى تتمية المكون الوجداني

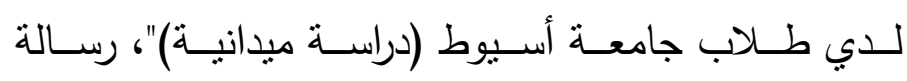

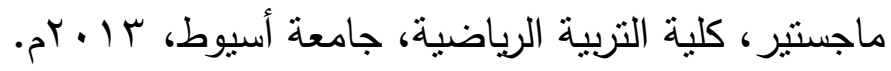

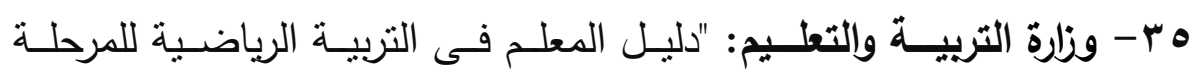

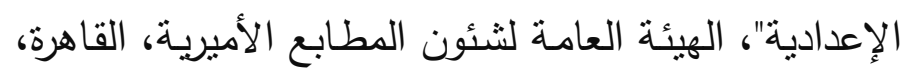

$$
\text { ثانياً: المراجع باللغة الإنجليزية }
$$

36-Med Calf, Richard; Marshall, Joe; rhoden, Clare:

Exploring the relation ship between physical

Education and enhancing Be haviour in pupils eme=otional Behaviroural difficulties, support of learning, 2006. 